\title{
Gas trap stability in the Zechstein Limestone from the Rudna Copper Mine (SW Poland)
}

\author{
Anna Poszytek ${ }^{1}$ (D) Barbara Rybak-Ostrowska ${ }^{1} \cdot$ Paweł Łukaszewski $^{1} \cdot$ Marcin Włodarczyk $^{2}$
}

Received: 11 October 2018 / Accepted: 27 December 2019 / Published online: 11 January 2020

(c) The Author(s) 2020

\begin{abstract}
A gas and crashed rock burst in 2009 in the Rudna Copper Mine was the motivation to re-investigate the dolomite succession of the first Permian cyclothem (Werra), which covers the ceiling section of the excavations. Gas traps were recognized by previous research; however, the stability of gas traps during mining operations has not been studied yet. Mitigation of future gas bursts requires a complex analysis of these gas traps, involving petrological, petrophysical and mechanical analysis of the reservoir dolomite facies. The results indicate the significant influence of dolomite texture, porosity and extent of late diagenetic dolomite cement on the reservoir and geomechanical properties, and the induced failure pattern of the dolomite facies. The mechanism of dolomite failure allowed for interpreting the degree of dolomite degassing during and after mining operations.
\end{abstract}

Keywords Dolomite $\cdot$ Zechstein Limestone $\cdot$ Gas traps $\cdot$ Porosity $\cdot$ Permeability $\cdot$ Strength $\cdot$ Strain $\cdot$ Failure pattern $\cdot$ Cataclastic deformation band $\cdot$ Mining operations

\section{Introduction}

Gas traps in the Rudna Copper Mine have a very low oil industrial potential because of small thicknesses and high contents of nitrogen. However, the gas-saturated horizon causes a threat zone to the mining operations. Since 2009, when the first burst of gas and crashed rocks took place, a number of gas occurrences have been noted above the ceiling of the excavations (Fig. 1b).

Gas occurs at the depth of ca. $1000 \mathrm{~m}$ b.s.l. (Fig. 1a, c) in dolo-grainstones with a higher porosity ( $>2 \%$ ) compared to other dolomites occurring below and above them (Fig. 2). The dolo-grainstones occur a few meters above the excavations within rocks of the Werra cyclothem (Poszytek et al. 2018). They are characterized by variable porosity from 2 to $15 \%$ (Poszytek et al. 2018). So far, petrophysical analysis of the gas trap stability has not been performed. Based on experimental research (Wong and Baud 2012), a hypothesis

Anna Poszytek

anna.poszytek@uw.edu.pl

1 Faculty of Geology, University of Warsaw, ul. Żwirki i Wigury 93, 02-089 Warsaw, Poland

2 KGHM Polska Miedź S.A., Rudna Mine, ul. H. Dąbrowskiego 50, 59-100 Polkowice, Poland was formulated that porosity is the most important factor differentiating the geomechanical properties of dolomite building traps for gas. However, dolomite texture and distribution of pore volume may also have effect on the geomechanical properties and the failure pattern (Patel and Shah 2015; Akram et al. 2017). The aim of this article is to describe the influence of petrophysical properties and failure patterns on the stability of gas traps during and after mining operations.

\section{Geological setting}

The Zechstein is a marine facies of late Permian (Lopingian) age located in the European Permian Basin. The Polish Permian Basin represents part of the Southern Permian Basin, which extends from the UK in the west to Latvia, Lithuania, and western Belarus in the east. The Zechstein Sea was created by rapid flooding of a late Permian intracontinental topographic depression (Peryt et al. 2010). The Polish Permian Basin is an area of widespread cyclic carbonate and evaporite sediments, representing four cyclothems: PZ1 (Werra), PZ2 (Strassfurt), PZ3 (Leine) and PZ4 (Wagner 1994). The PZ1 (Werra) cyclothem is represented by Basal Limestone (Ca0), Kupferschiefer (T1), Zechstein Limestone (Ca1), Lower Anhydrite (A1d), Older Rock Salt (Na1), and 


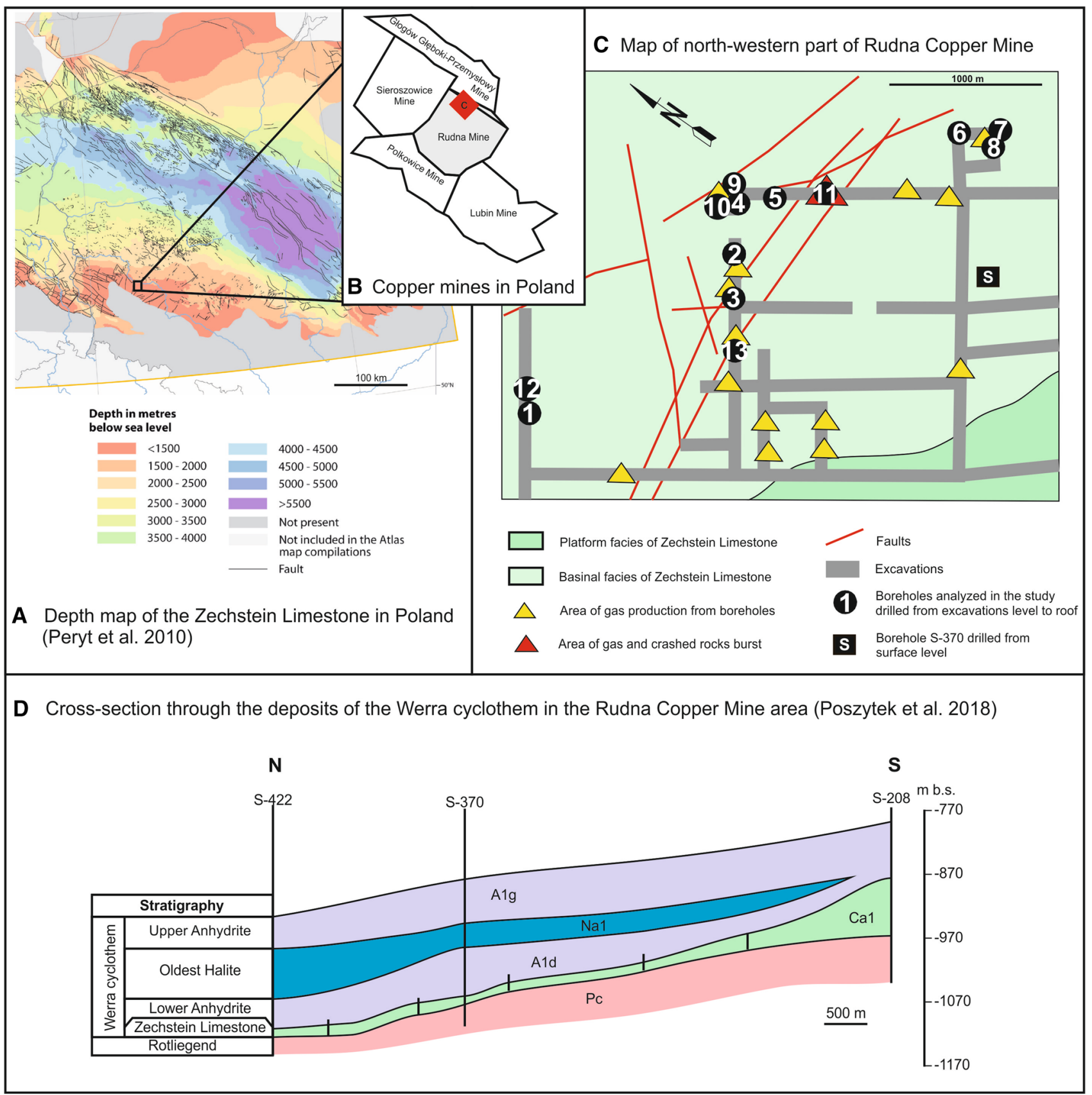

Fig. 1 Location of the study area

Upper Anhydrite (A1g) (Peryt and Oszczepalski 2007). The Zechstein Limestone is generally developed in two facies: platform and basinal (Peryt 1984). The platform facies are over up to $120 \mathrm{~m}$ thick and occur in the nearshore parts of the basin. The basinal facies do not exceed $10 \mathrm{~m}$ in thickness. The Zechstein is covered by Mesozoic and Cenozoic sediments (Wagner 1994).

The Zechstein Limestone is well explored in the southwestern section of the Polish Zechstein Basin due to deep mining shafts and numerous boreholes documenting copper mineralization in the Lubin-Głogów area (Fig. 1) (Podemski 1973; Oszczepalski 1980; Kijewski 1981). Exploitation of copper deposits is carried out from the topmost parts of the Weissliegend, the Kupferschiefer, and the basal part of the Zechstein Limestone (Piestrzyński 2007). Copper mines are localized at the boundary between the platform and basinal facies of the Zechstein Limestone (Fig. 1). The basinal facies in this area are similar to those described from the northern section of the Fore-Sudetic Monocline (Peryt 1978; Peryt and Ważny 1980). Moreover, the middle part of the 


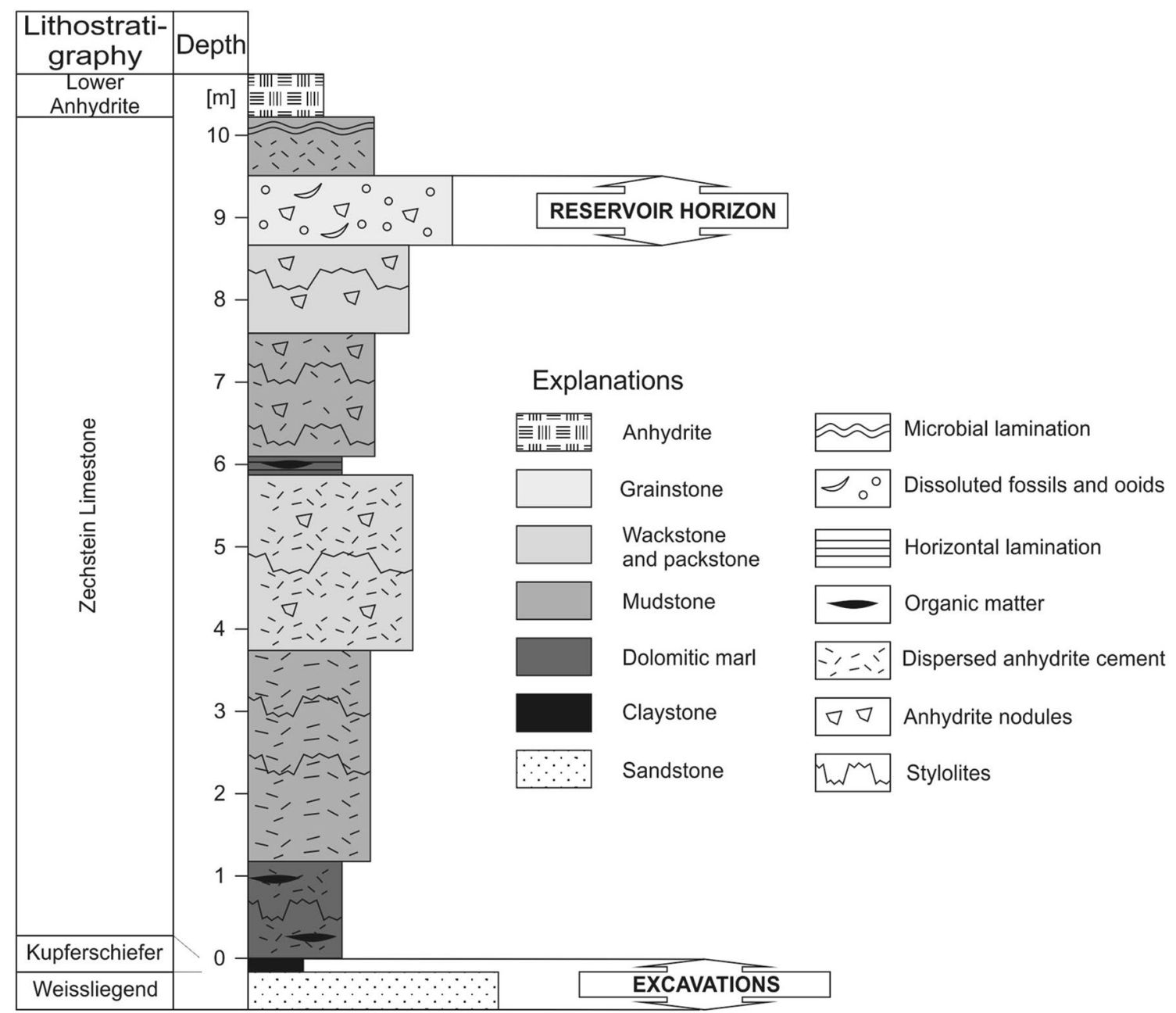

Fig. 2 Lithological-sedimentological log of the Zechstein Limestone in the borehole drilled in the ceiling of the excavation in the Rudna Copper Mine (Poszytek and Suchan 2016)

Zechstein Limestone succession in the Rudna Copper Mine contains a ca. 1-m-thick unit of grainstone characterized by high porosity (up to $15 \%$ ) and very low permeability (up to few mD) (Fig. 2-Poszytek and Suchan 2016). Gas accumulations form small stratigraphic traps sealed by dolomite with low porosity and permeability (Poszytek et al. 2018).

A previous study has indicated that the Zechstein Limestone in the Rudna Copper Mine area is developed in the basinal facies (Poszytek and Suchan 2016) and has a thickness of about $10 \mathrm{~m}$ (Fig. 2). Based on the macroscopic description of cores and microscopic observations, four facies may be identified in the succession (Poszytek and Suchan 2016): dolomitic marl; dolo-mudstone; dolowackestone and dolo-packstone; and dolo-grainstone. The dolo-grainstone is characterized by high porosity (up to $15 \%$ ) and low permeability (up to few $\mathrm{mD}$ ), and creates a tight reservoir horizon saturated with gas (Poszytek et al. 2018). Nitrogen (ca. 60\%) predominates in the gas composition. Other components include carbon dioxide (ca. 20\%), methane (up to 10\%), higher hydrocarbons, carbon monoxide, and hydrogen. Gas pressure in the boreholes varies from 0.6 to $2 \mathrm{MPa}$ and changes over time. However, degassing disappears after 1 month from most boreholes.

\section{Methods}

The samples were taken from boreholes drilled in the ceiling of the excavations using small diameter, full-core technology. The core diameter was approx. $3.6 \mathrm{~cm}$. The excavations occur at the depth of $1000 \mathrm{~m}$ b.s.l. (Fig. 1c), where temperature is ca. $40^{\circ} \mathrm{C}$. Boreholes were drilled to determine the presence of gas in the ceiling and the possible degassing of the rock massif. The gas reservoir horizon occurs a few meters above the ceiling of the excavations within Zechstein Limestone, which is part of the first Zechstein cyclothem PZ1 (Werra). The thickness of Zechstein Limestone is ca. $10 \mathrm{~m}$. Boreholes were drilled through Zechstein Limestone 
and passed into the overlying anhydrite (Fig. 2). Thirteen boreholes located in the gas threat zone of the Rudna Copper Mine were selected for this study (Fig. 1). Fourteen samples were taken from the gas reservoir horizon (grainstonesFig. 2) - one sample from each borehole and an additional sample from borehole 7 (Table 1).

All samples were examined using tensile strength tests. Selected samples (Table 1) were examined using strength tests and triaxial compressive strength tests (Faculty of Geology, University of Warsaw). All samples examined by geomechanical tests were microscopically described before the tests. X-ray microtomography (MCT) analyses were performed before and after uniaxial compressive strength tests and triaxial compressive strength tests (Table 1). X-ray microtomography was conducted in the Oil and Gas Institute-National Research Institute in Kraków, Poland. X-ray microtomography (MCT) was performed to assess the pore distribution of the dolomite and to determine the fractures after uniaxial and triaxial compressive strength tests. Failure patterns developed during geomechanical tests were also described macro- and microscopically.

\section{Microfacies analysis}

Twenty-seven uncovered thin sections were made from the taken samples, which were then impregnated with blue resin. The thin sections were examined using polarizing and scanning electron microscopy (Faculty of Geology, University of Warsaw) to recognize the structure, texture and porosity of the dolomite. The results were combined with previous detailed studies of the dolomite reservoir properties and diagenesis results (Poszytek et al. 2018).

\section{Computed X-ray microtomography}

$\mathrm{X}$-ray MCT is presently a state-of-the-art study method (Van Geet et al. 2001); it is a non-destructive technique allowing for 3D visualization of the internal structure of an object (Ketcham and Carlson 2001; Stock 2008; Zapalski and Dohnalik 2013; Couves et al. 2016; Poszytek et al. 2017, 2018).

The measurements were performed with a Benchtop CT160Xi (Nikon) X-ray microtomograph. The X-ray source installed in the apparatus emits a conical beam of photons with an acceleration voltage in the range of $40-160 \mathrm{kV}$ and a resolution up to $3 \mu \mathrm{m}$; the samples examined for this study had a resolution of $6 \mu \mathrm{m}$.

$\mathrm{X}$-ray microtomography (MCT) analysis was carried out twice on samples prepared for mechanical testing: before and after uniaxial compressive strength tests, and triaxial compressive strength tests.

The results of the microtomographic studies were presented in the form of 3D visualizations of the pore space and on charts. 3D visualization enables a qualitative analysis of the characteristics of the pore space including the assessment of the anisotropy of the sample's pore network pattern (Svitelman and Dinariev 2013). In turn, charts showing the pore distribution display the quantitative characteristics of each sample and its comparison with the remaining samples. The quantitative evaluation of porosity was done using MAVI software.

Table 1 Methods used in study

\begin{tabular}{|c|c|c|c|c|c|c|}
\hline $\begin{array}{l}\text { Borehole } \\
\text { numer/sample } \\
\text { number }\end{array}$ & $\begin{array}{l}\text { Tensile strength } \\
\text { tests and micros- } \\
\text { copy observation } \\
\text { before tests }\end{array}$ & $\begin{array}{l}\text { Uniaxial compres- } \\
\text { sive strength tests } \\
\text { and microscopy } \\
\text { observation before } \\
\text { tests }\end{array}$ & $\begin{array}{l}\text { Triaxial compres- } \\
\text { sive strength tests } \\
\text { and microscopy } \\
\text { observation before } \\
\text { tests }\end{array}$ & $\begin{array}{l}\text { Computed microto- } \\
\text { mography before } \\
\text { and after uni- } \\
\text { axial compressive } \\
\text { strength tests }\end{array}$ & $\begin{array}{l}\text { Computed } \\
\text { microtomography } \\
\text { before and after } \\
\text { triaxial compressive } \\
\text { strength tests }\end{array}$ & Failure pattern \\
\hline 1 & + & + & - & - & - & + \\
\hline 2 & + & - & - & - & - & + \\
\hline 3 & + & + & + & + & + & + \\
\hline 4 & + & - & - & - & - & + \\
\hline 5 & + & - & - & - & - & + \\
\hline 6 & + & + & - & - & - & + \\
\hline 7 (a) & + & - & - & - & - & + \\
\hline $7(b)$ & + & + & + & + & + & + \\
\hline 8 & + & - & - & - & - & + \\
\hline 9 & + & - & - & - & - & + \\
\hline 10 & + & + & + & + & + & + \\
\hline 11 & + & + & - & - & - & + \\
\hline 12 & + & + & + & - & + & + \\
\hline 13 & + & + & + & - & + & + \\
\hline
\end{tabular}


3D visualization of the pore space was made using AVIZO software. Visualizing the pore network subdivided into subgroups was particularly useful. Each subgroup represents a set of interconnected pores that were not connected to other subgroups. The subgroups were subdivided into classes according to their volume $(1$ voxel $=6 \times 6 \times 6 \mu \mathrm{m}=2$ $16 \mu^{3}$ ). Six volume classes were distinguished in the porosity subgroups per logarithmic scale. The subgroups were marked with specific colors: 1-9 voxels-violet, 10-99 voxels-blue, 100-999 voxels-red, 1000-9999 voxels-green, 10,000-99,999 voxels-white, > 100,000 voxels-yellow.

Additionally, porosity was also visualized on three perpendicular planes together with the fractures after uniaxial and triaxial compressive strength tests.

Charts of pore distribution were constructed based on the subdivision of the pore space into subgroups. The charts showed the percentage distribution of each particular volume class in the pore network, indicating which class dominated in the samples. A greater domination by high-pore classes (interconnected pores) means better reservoir parameters of the rock (Poszytek et al. 2017). Quantitative analysis of the variability of the pore network was based on charts showing the distribution of pore classes.

The values of porosity from X-ray microtomography were lower than from microscopic observations (Poszytek et al. 2017). The reason was the resolution of $X$-ray microtomography, which was $6 \mu \mathrm{m}$; in consequence, pores below $6 \mu \mathrm{m}$ were not recognized by X-ray microtomography. However, $\mathrm{X}$-ray microtomography results were the basis for comparisons of the samples before and after uniaxial compressive strength tests and triaxial compressive strength tests.

\section{Geomechanical testing}

The aim of the geomechanical testing was to determine the strength and deformation properties of the dolomite from the area of gas explosion hazard in the Rudna Copper Mine. Geomechanical testing included

- tensile strength tests using the Brazilian method,

- uniaxial compressive strength tests,

- triaxial compressive strength tests.

\section{Splitting (indirect) tensile strength tests}

The tensile strength was determined using the Brazilian test method, in accordance with the Polish Standard PN-G04302-97 (1997). The tests were performed on 14 dolomite samples. Drilling core sections with a diameter of approx. $3.6 \mathrm{~cm}$ were cut to a height equal to half of the diameter.

The Brazilian test method consists of loading a cylindrical rock sample with a compression force that is distributed evenly along the diametric line. During the tensile strength test, the load was continuously increased with a standard constant stress rate of approximately $0.3 \mathrm{MPa} / \mathrm{s}$ (load rate of $6 \mathrm{kN} / \mathrm{min}$ ). The failure load (Pcr) was recorded with an accuracy to the nearest $0.1 \mathrm{kN}$. The splitting tensile strength (Rr) was calculated according to the formula:

$R r=2 P c r / \pi d h$,

where Pcr maximum load applied at failure $(\mathrm{N})$, h height of the specimen $(\mathrm{mm})$, and diameter of the specimen $(\mathrm{mm})$.

\section{Uniaxial compressive strength tests}

Strength tests under uniaxial compression conditions allowed for determining

- the uniaxial compressive strength $\left(R_{c}=\sigma_{\max }\right)$;

- two elasticity parameters: Young's modulus $(E)$ and Poisson's ratio $(v)$.

Uniaxial compressive strength tests were performed according to the Polish Standard PN-EN 1926:2007 (2007) test procedure "Natural stone test methods-Determination of compressive strength", also referring to American and ISRM (International Society for Rock Mechanics) standards (ASTM D2938-95 1995; ISRM 2007a).

Eight dolomite samples were tested (Table 1). Samples were selected based on results of tensile strength tests. Drilling core sections with a diameter of approx. $3.6 \mathrm{~cm}$ were cut to a length-to-diameter ratio equal to one. The strength tests were performed on samples after drying at $70{ }^{\circ} \mathrm{C}$ to a constant weight, with a thermal equilibrium reached at $20{ }^{\circ} \mathrm{C}$ after $24 \mathrm{~h}$. The strength tests were carried out in the MTS-815 rigid press produced by MTS System Corporation.

Load was applied continuously during the test, with a standard constant stress rate of $1 \mathrm{MPa} / \mathrm{s}$. For samples with a diameter of about $37 \mathrm{~mm}$, the load rate was $65 \mathrm{kN} / \mathrm{min}$. Load changes $(P)$, axial strain $\left(\varepsilon_{z}\right)$ and lateral strain $\left(\varepsilon_{x y}\right)$ were recorded. The value of volume strain $\left(\varepsilon_{v}\right)$ was determined on the basis of the values of the axial strain and the lateral strain:

$\varepsilon_{v}=\varepsilon_{z}+2 \varepsilon_{x y}$.

The value of the maximum load at failure $(P)$ was determined to the nearest $1 \mathrm{kN}$. Next, the value of the uniaxial compressive strength $\left(R_{c}=\sigma_{\max }\right)$ was calculated as follows:

$R c=\frac{P}{A}[\mathrm{MPa}]$,

where $P$ maximum load at failure $[\mathrm{kN}]$, and A cross-sectional area $\left[\mathrm{mm}^{2}\right]$.

Experimental deformation stress-axial, lateral and volumetric strain curves (Fig. 3) were plotted during the 
tests. They were used as the basis for determining the elasticity parameters according to Hallbauer et al. (1973) and Pinińska et al. (2015), and European and American Standards (Eurocod 7 - PN-EN-1997-2:2009 2009; ASTM Designation: D3148-02 1993):

- Young's modulus $(E)$ is defined as the average modulus of the relationship between the stress $(\sigma)$ and the axial strain $\left(\varepsilon_{z}\right)$ of the straight line portion of the stress-strain curve.

- Poisson's ratio $(v)$ is defined as the relationship between the axial strain $\left(\varepsilon_{z}\right)$ and the lateral strain $\left(\varepsilon_{x y}\right)$. Poisson's ratio was determined in the full linearity range of all deformation characteristics, to the border of the microdilatancy phase determined in accordance with the phenomenological description of Hallbauer et al. (1973).

- The stress at the threshold of proper dilatancy $\left(\sigma_{D}\right)$ is defined as strength corresponding to the maximal volumetric strain.

The scheme of strength determination for the threshold of proper dilatancy $\left(\sigma_{D}\right)$ and the range of linear characteristics for Young's modulus $(E)$ and Poisson's ratio $(\nu)$ are presented in Fig. 3.

It should be emphasized that a crucial element assessing rock behavior under load is the determination of the threshold of proper dilatancy at the boundary between stable and unstable cracking, indicating the loss of rock structure stability (Łukaszewski 2013).

\section{Triaxial compressive strength tests}

Strength tests under triaxial compression conditions were carried out using a comprehensive multipurpose test unit with a thermocouple chamber. The key component of the

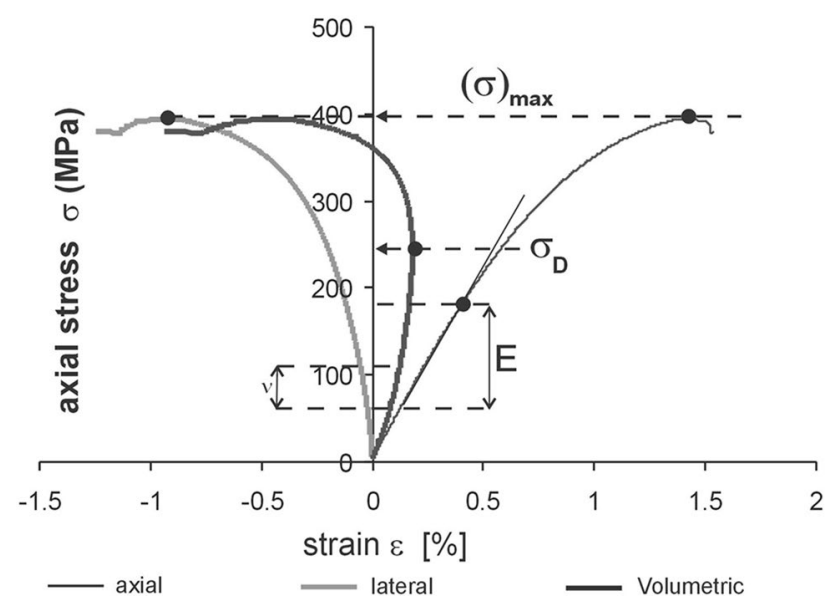

Fig. 3 Scheme of determining the analyzed parameters based on uniaxial strength tests test unit is the rigid strength press MTS- 815 produced by MTS Systems Corporation.

The aim of the triaxial test was to determine two elastic parameters: Young's modulus $(E)$ and Poisson's ratio $(v)$ at in situ conditions. Single classic failure tests were performed under triaxial compression. The tests were conducted using MTS's test and interpretation procedures, which are based on American standards (ASTM D2664-95a 1995) and on the recommendations of ISRM's “Suggested Method for Determining the Strength of Rock Materials in Triaxial Compression" (ISRM 2007b), described in more detail further in this chapter.

Triaxial compressive strength tests were conducted on five cylindrical samples with a diameter of approx. $36 \mathrm{~mm}$ and a height of $72 \mathrm{~mm}$ (length-to-diameter ratio equal to two). The samples were taken from reservoir horizon in five boreholes (Fig. 2). They were previously examined by uniaxial compressive tests (Table 1). The samples were tested at temperature set to $40{ }^{\circ} \mathrm{C}$ and confining stress set to $\sigma_{3}=20 \mathrm{MPa}$, which corresponds to conditions at a depth of $1000 \mathrm{~m}$ b.s.l.

The research used the single classic test. It is one of the three types of tests recommended by the International Society for Rock Mechanics (ISRM) for triaxial compression testing (ISRM 2007b).

The test ran in two stages. First, confining stress was applied with a stress rate of $10 \mathrm{MPa} / \mathrm{min}$. Second, the rock sample was axially loaded with a constant rate of strain equal to $10^{-5} / \mathrm{s}^{-1}$ until failure was observed.

During the compression stage, the axial and lateral strains of the samples were measured by extensometers. Real-time stress recording ensured obtaining deformation curves, which were the basis for determining Young's modulus $(E)$ and Poisson's ratio $(\nu)$.

The values of Young's modulus $(E)$ and Poisson's ratio $(v)$, and the differential stress for the threshold of proper dilatancy $\left(\sigma_{1}-\sigma_{3}\right)_{D}$ were determined in the same way as in the uniaxial compressive strength tests.

\section{Analysis of failure pattern}

Samples after the geomechanical tests were analyzed macroscopically for the description of the geometry and classification of the induced faults and fractures in relation to the dolomite facies. Thin sections of the samples after uniaxial and triaxial compression strength tests were cut perpendicularly to the strike of the induced faults and fractures. It is significant that the mineral composition of the dolomite, especially the properties of anhydrite influenced the quality of the thin sections. Detailed analysis of microstructures related to the damage of the dolomite that have resulted from the geomechanical tests was obtained by means of the Polarizing Microscope Nikon Eclipse LV 100 POL with a 
scanning table. Acquisition of images was made using NIS Elements software.

\section{Results}

\section{Dolomite facies and their porosity and permeability}

The gas-saturated horizon occurs at the depth of $1000 \mathrm{~m}$ b.s.l. within the Zechstein Limestone, which is part of the first Zechstein cyclothem (Werra). The reservoir horizon contains dolomites with a variable texture and porosity (2-15\%). Based on the previous studies (Poszytek et al. 2018), dolomite from the reservoir horizon has been subdivided depending on its texture into dolosparite and dolomicrite. Dolosparite was then subdivided into two groups depending on its reservoir properties: dolosparite with high porosity and permeability (porosity $8-15 \%$, permeability ca. $3.25 \mathrm{mD}$ ) and dolosparite with low porosity and permeability (porosity $4-8 \%$, permeability ca. $0.06 \mathrm{mD}$ ). The dolomicrite is characterized by porosity of $2-4 \%$ and lack of permeability; therefore, it was termed the sealing dolomicrite. The reservoir properties of the reservoir horizon are significantly influenced by sedimentary conditions and diagenetic processes (Poszytek and Suchan 2016). Reservoir dolomite was formed as a result of redeposition from the carbonate platform to the basin plain. The most important diagenetic process was dissolution of dolomite during burial and later cementation by dolomite.

\section{Dolosparite with high porosity and permeability (Dsh)}

The rock has a hypidiotopic texture and is composed of dolosparite, formed of subhedral and euhedral crystals ca. $50 \mu \mathrm{m}$ in size (Fig. 7a). Porosity occurs as inter-crystalline pores and voids partly cemented by euhedral dolomite crystals. Anhydrite cement partly fills the pore space (Fig. 4a, b). Porosity calculated from microscopic images was $>8 \%$

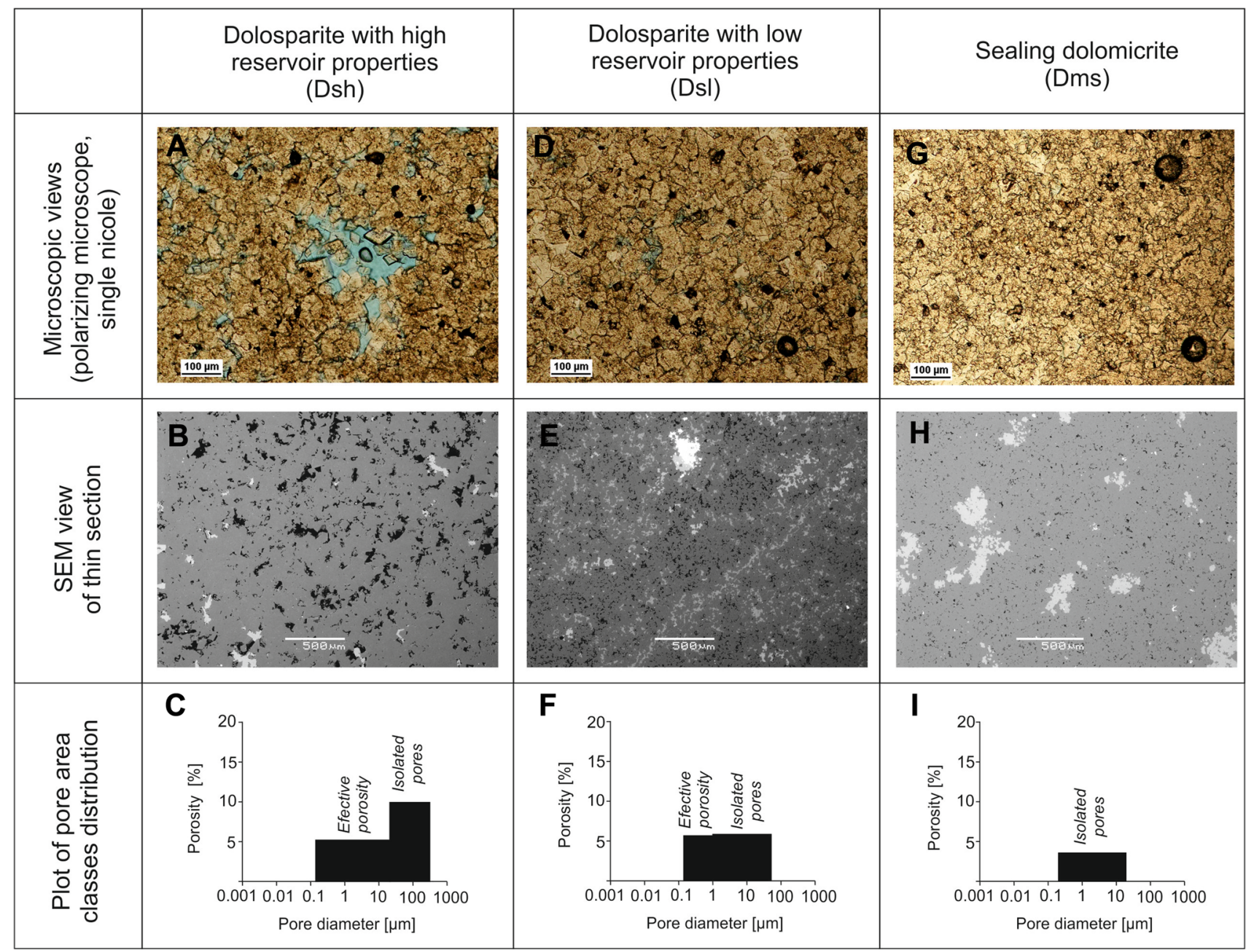

Fig. 4 Microscopic views of different types of dolomite from the reservoir horizon in the Rudna Copper Mine (Poszytek et al. 2018-modified) 
(Poszytek et al. 2018). The pores varied in size from 10 to $300 \mu \mathrm{m}$ (Fig. 4b). Occurrence of big voids $(>100 \mu \mathrm{m})$ suggests intensive dissolution of this dolomite during burial. However, all pores and voids are characterized by irregular shapes with sharp edges, which resulted from the partly cementation of the pores by euhedral and subhedral dolomite crystals (Fig. 4a). The pores were elongated; their length reached up to $300 \mu \mathrm{m}$, while the width was approx. $50 \mu \mathrm{m}$. Sometimes the pores were connected with each other by fine channels but in a very small area. A previous study of the reservoir properties indicates that the dolomite is characterized by high effective porosity and high content of isolated pores (total porosity ca. 15\%)—Fig. 4c (Poszytek et al. 2018).

\section{Dolosparite with low porosity and permeability (Dsl)}

The rock has a hypidiotopic texture and is composed mainly of dolosparite, formed of subhedral and euhedral crystals ca. $50 \mu \mathrm{m}$ in size. Porosity occurs as intercrystalline pores (Fig. 4d, e). Dolomite and anhydrite cements mostly filling the pore space formed zones without porosity (Fig. 4f, h). Porosity obtained from microscopic observations was 4-8\% (Poszytek et al. 2018). Pores with diameters of 5-50 $\mu \mathrm{m}$ dominated and were sometimes connected with each other by thin channels on small areas. The pores were irregularly shaped; some of them were elongated (Fig. 4d, e). Isolated pores dominated. Dolomite texture and pore character suggest that it was not intensively dissolved compared to the previously discussed dolomite (Dsh). Additionally, the formed pores were intensively cemented by dolomite. Therefore, this dolomite is characterized by reduced effective porosity and high content of isolated pores (total porosity ca. 10\%)—Fig. 4f (Poszytek and Suchan 2016).

\section{Sealing dolomicrite (Dms)}

The rock has a xenotopic texture and is mainly composed of dolomicrite, formed of anhedral crystals ca. $30 \mu \mathrm{m}$ in size (Fig. 4g). Very fine porosity occurs as intercrystalline pores (Fig. 4h). Anhydrite and dolomite cement mostly fills the pore space. Porosity obtained from microscopic observations was $2-4 \%$ (Poszytek et al. 2018). Pores with diameters at 5-10 $\mu \mathrm{m}$ dominated and created a very fine, diffuse porosity network (Fig. 4h). There were no connections between the pores. Dolomite texture and pore character suggest that this dolomite was probably not dissolved, because of low permeability and low availability for fluids. Therefore, this dolomite is characterized by the lack of effective porosity and a $4 \%$ content of isolated pores-Fig. 4i (Poszytek et al. 2018).
Results of the applied methods are presented with regard to dolomite facies emphasizing the porosity observed before and after the geomechanical tests.

\section{Computed microtomography}

\section{Computed microtomography analysis before geomechanical tests}

Porosity of dolosparite with high porosity and permeability (Dsh) calculated from X-ray MCT exceeded 2\% (Fig. 5a). Plots of the pore volume classes showed the presence of the highest class ( $>100,000$ voxels). However, this class did not dominate in the photomicrograph observations, with the prevalent classes being those of 1000-9999 and 10,000-99,999 voxels (Fig. 5b). Porosity distribution was uniform in the 3D images. Pores with a smaller volume (1-999 voxels) were found in small, irregular areas between pores with larger volumes ( $>1000$ voxels). Larger pores ( $>1000$ voxels) were sometimes connected with thin channels over very small areas (Fig. 5a). Porosity in the horizontal plane was greater than that in the vertical planes (Fig. 5c), probably as a result of horizontal elongation of the pore shapes. The pores were not connected with each other in either orthogonal plane.

Porosity of dolosparite with low porosity and permeability (Dsl) calculated from X-ray MCT was less than 2\% (Fig. 5d). Plots of the pore volume classes show the absence of the largest class ( $>100,000$ voxels). Pores in the class of $100-999$ voxels prevailed (Fig. 5e). Pores on the 3D image were irregular and sometimes connected with each other (Fig. 5d). Porosity distribution over three orthogonal planes was similar, and the pores were not connected (Fig. 5f).

Porosity of sealing dolomicrite (Dms) calculated from X-ray MCT was less than 1\% (Fig. 5g). Plots of pore volume classes show a clear dominance of the lowest volume classes (Fig. 5h), and pores with volumes of up to 99 voxels occupied more than $70 \%$ of the pore space. There were no pores with volumes $>10,000$ voxels. Porosity distribution on three orthogonal planes was similar (Fig. 5i). The pores were very fine and not connected.

\section{Computed microtomography analysis after uniaxial compressive strength tests}

Porosity of dolosparite with high porosity and permeability (Dsh) decreased from above 2\% to $1.4 \%$ (Fig. 6a, Table 2). The tests resulted in the formation of a steeply dipping fracture (ca. $85^{\circ}$ ) with higher porosity in relation to the host rock (Fig. 6c). In addition, a distinct zone of higher porosity perpendicular to the fracture and with a dip angle of ca. $50^{\circ}$ is visible. Fracture porosity represents the highest class of porosity (Fig. $6 \mathrm{~b}$ ) and includes ca. $20 \%$ of the sample 


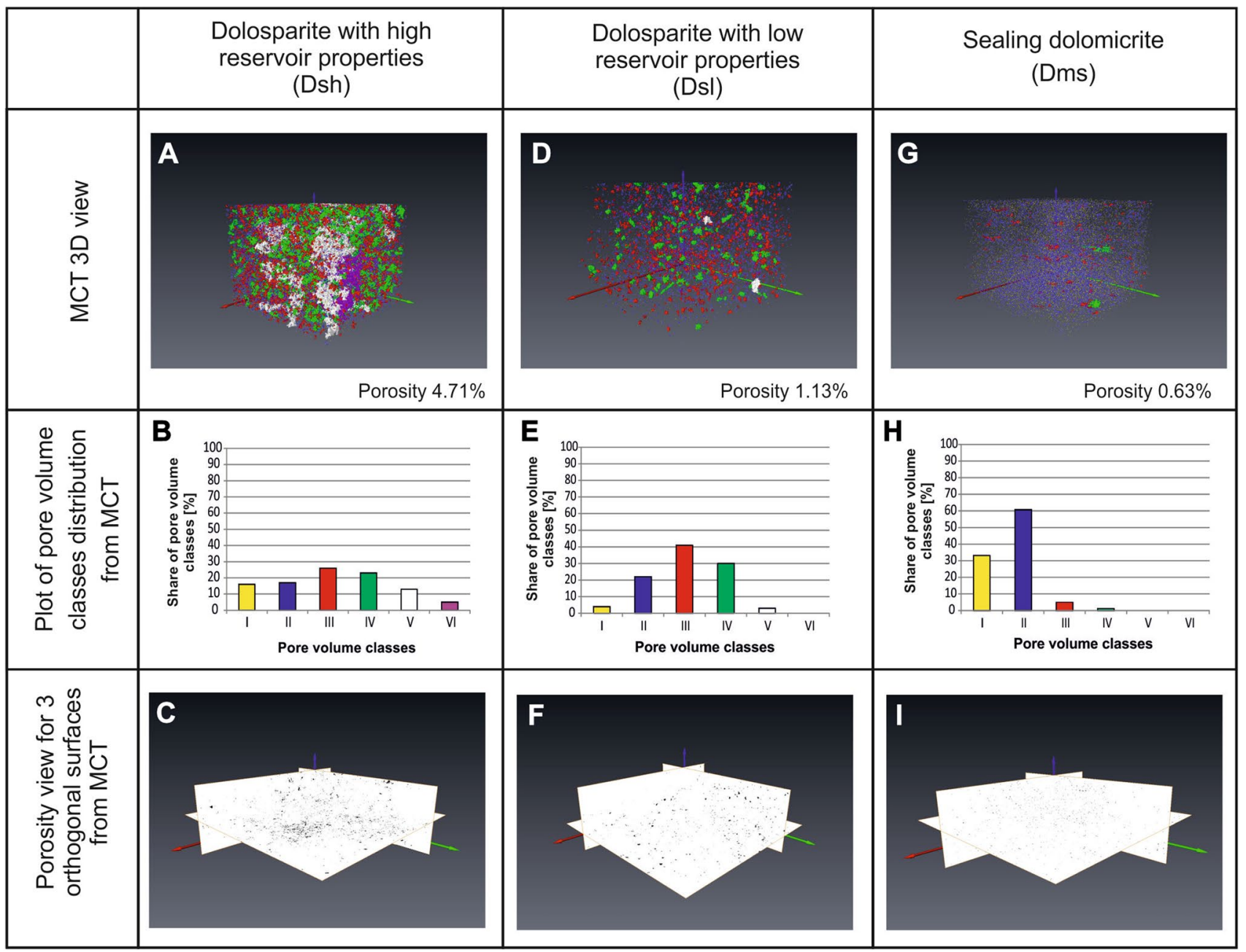

Fig. 5 Results of MCT analysis before geomechanical tests (Poszytek et al. 2018, supplemented)

porosity. Hence, rock fabric porosity is ca. $1.12 \%$. This indicates that the rock fabric porosity was reduced by almost $50 \%$ after uniaxial compressive strength tests (Table 2). The distribution of pores indicates an increase in the percentage of pores in the II pore volume class at the expense of other classes (Figs. 5b, 6b).

Porosity of dolosparite with low porosity and permeability (Dsl) decreased from 1.13 to $0.5 \%$ (Fig. 6d, Table 2). Fractures were not recognized in the samples (Fig. 6d, f). Nevertheless, a nearly horizontal discrete zone of higher porosity is clearly recognizable. The distribution of pores indicates an increase in the percentage of pores in the I and II pore volume classes at the expense of other classes (Figs. 5e, 6e).

Porosity of sealing dolomicrite (Dms) increased from 0.63 to $0.9 \%$ (Fig. $6 \mathrm{~g}$, Table 2). Distinct fractures were not recognized in these samples (Fig. 6g, i); however, a discrete zone of pores was formed (Fig. 6i). The distribution of pores indicates a small increase in the percentage of pores in the
I and II pore volume classes at the expense of other classes (Figs. 5h, 6h).

\section{Computed microtomography after triaxial compressive strength tests}

Porosity of dolosparite with high porosity and permeability (Dsh) decreased from 4.71 to $0.6 \%$ (Fig. 7a, Table 3). The tests resulted in the formation of a complementary system of two steeply dipping fractures with one being distinct, and the opposite one that is more widespread and forms a rather discrete zone-both with a higher porosity in relation to the host rock (Fig. 7a). The angle between the fractures is ca. $30^{\circ}$. The distinct fracture represents the V and VI classes of porosity (Fig. $7 \mathrm{~b}$ ) and includes ca. $70 \%$ of the sample porosity. Hence, the host rock fabric porosity is ca. $0.18 \%$. This indicates that host rock fabric porosity was reduced by more than $90 \%$ after the triaxial compressive strength tests (Table 3). The distribution of pores indicates an increase in 


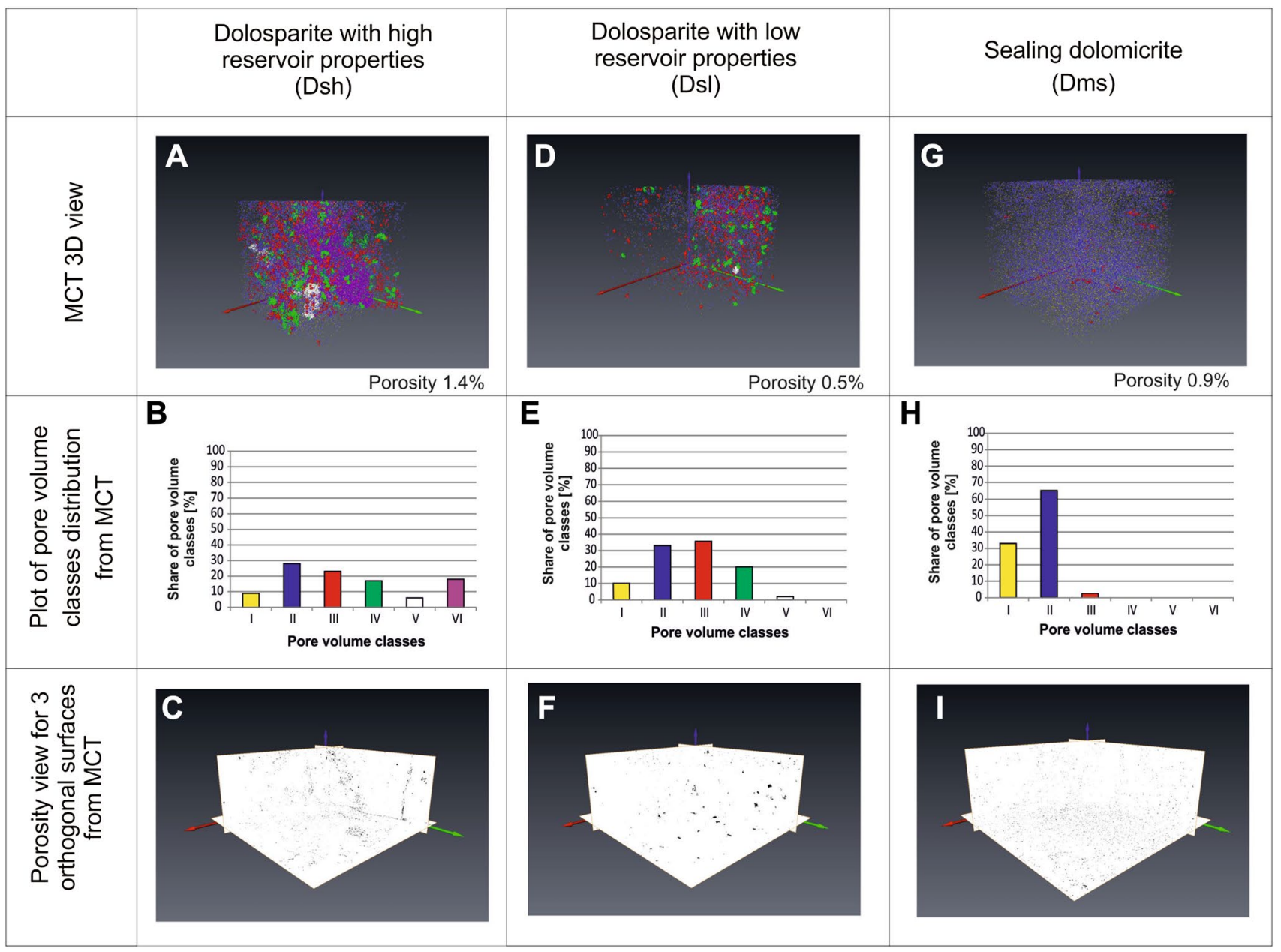

Fig. 6 Results of MCT analysis after uniaxial compressive strength tests

Table 2 Porosity change after uniaxial compressive strength tests

\begin{tabular}{lllll}
\hline Dolomite facies & $\begin{array}{l}\text { MCT primary } \\
\text { porosity [\%] }\end{array}$ & $\begin{array}{l}\text { MCT porosity after uniaxial compres- } \\
\text { sive strength tests }\end{array}$ \\
\cline { 3 - 5 } & & $\begin{array}{l}\text { Total } \\
\text { porosity } \\
{[\%]}\end{array}$ & $\begin{array}{l}\text { Fracture } \\
\text { porosity } \\
{[\%]}\end{array}$ & $\begin{array}{l}\text { Rock fabric } \\
\text { porosity } \\
{[\%]}\end{array}$ \\
\hline Dolosparite with high reservoir properties (Dsh) & 2.04 & 1.4 & 0.28 & 1.12 \\
Dolosparite with low reservoir properties (Dsl) & 1.13 & 0.5 & 0.00 & 0.5 \\
Sealing dolomicrite (Dms) & 0.63 & 0.9 & 0.00 & 0.9 \\
\hline
\end{tabular}

the percentage of pores in the II pore volume class at the expense of other classes (Figs. 5b, 6b).

Porosity of dolosparite with low porosity and permeability (Dsl) increased from 1.87 to $2.3 \%$ (Fig. 7d, Table 3). The tests resulted in the formation of one steeply dipping, distinct fracture of high porosity and two almost horizontal discrete zones of higher porosity in relation to the host rock (Fig. 7d). The fracture porosity represents the highest class of porosity (Fig. 7e) and includes ca. $50 \%$ of the sample porosity. Hence, the host rock fabric porosity is ca. $1.15 \%$ (Table 3). This indicates that the host rock fabric porosity was reduced by $60 \%$ after triaxial compressive strength tests. The distribution of the pores indicates a decrease in the percentage of pores in the II pore volume class at the expense of other classes (Figs. 5e, 7e).

Porosity of sealing dolomicrite (Dms) increased from $0.63 \%$ to $1.6 \%$ (Fig. $7 \mathrm{~g}$, Table 3 ). The tests resulted in the formation of one less distinct fracture in comparison to 


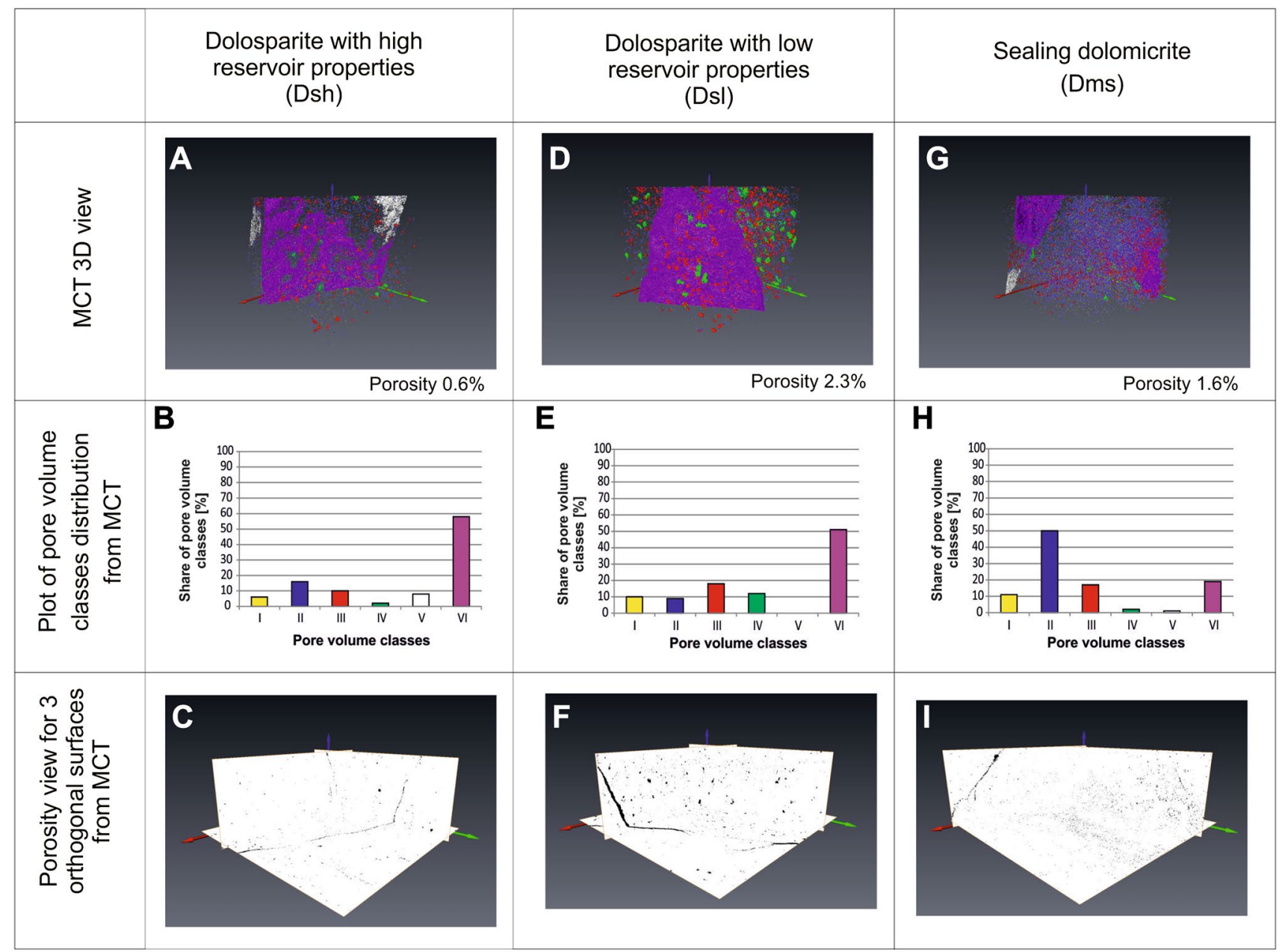

Fig. 7 Results of MGT analysis after triaxial compressive strength tests

Table 3 Porosity change after triaxial compressive strength tests

\begin{tabular}{lllll}
\hline Dolomite facies & $\begin{array}{l}\text { MCT primary } \\
\text { porosity [\%] }\end{array}$ & $\begin{array}{l}\text { MCT porosity after triaxial compres- } \\
\text { sive strength tests }\end{array}$ \\
\cline { 3 - 5 } \cline { 3 - 5 } & & $\begin{array}{l}\text { Total } \\
\text { porosity } \\
{[\%]}\end{array}$ & $\begin{array}{l}\text { Fracture } \\
\text { porosity } \\
{[\%]}\end{array}$ & $\begin{array}{l}\text { Rock fabric } \\
\text { porosity } \\
{[\%]}\end{array}$ \\
\hline Dolosparite with high reservoir properties (Dsh) & 4.71 & 0.6 & 0.42 & 0.18 \\
Dolosparite with low reservoir properties (Dsl) & 1.87 & 2.3 & 1.15 & 1.15 \\
Sealing dolomicrite (Dms) & 0.63 & 1.6 & 0.32 & 1.28 \\
\hline
\end{tabular}

other dolomite facies and a horizontal discrete zone-both of variable but generally higher porosity in relation to the host rock (Fig. 7g). The fracture porosity occurs in the $\mathrm{V}$ and VI classes of porosity (Fig. 7h) and includes ca. $20 \%$ of the sample porosity. Hence, the rock fabric porosity is ca. $1.28 \%$. This indicates that the rock fabric porosity increased more than twice after triaxial compressive strength tests (Table 3). The distribution of pores indicates a decrease in the percentage of pores in the I pore volume class (Figs. 5h, 6h).

\section{Geomechanical tests}

\section{Tensile (indirect) strength}

The tensile strength $\left(R_{r}\right)$ of the analyzed dolomite ranged from 7.3 to $17.1 \mathrm{MPa}$. It varied depending on the dolomite facies (Fig. 8). Dolosparite with low porosity and permeability (Dsl) showed the highest tensile strength. Sealing dolomicrite (Dms) showed medium tensile strength, while 


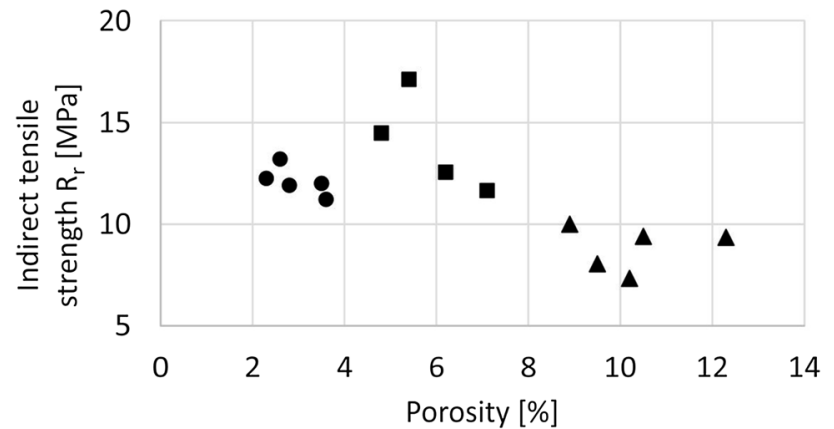

$\Delta$ Dolosparite with high reservoir properties (Dsh)

- Dolosparite with low reservoir properties (Dsl)

- Sealing dolomicrite (Dms)

Fig. 8 Relation between porosity and tensile strength

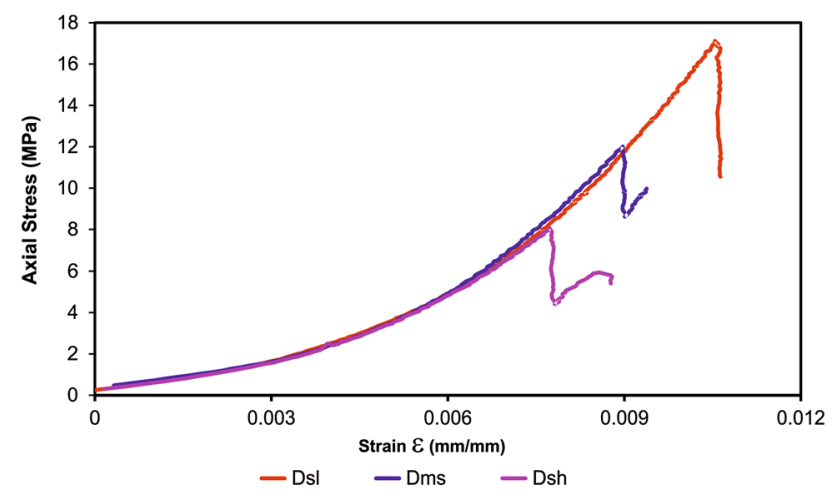

Fig. 9 Axial stress vs. strain from uniaxial indirect tensile strength tests

dolosparite with high porosity and permeability (Dsh) showed the lowest tensile strength.

The dolomite facies are characterized by a very similar deformation path; however, they may be differentiated by tensile strength (Fig. 9).

\section{Uniaxial compressive strength}

Large differences were also obtained for uniaxial compressive strength $\left(R_{c}\right)$. The values ranged between 77 and $200 \mathrm{MPa}$. The differentiation depended on the dolomite facies and their different porosity (Fig. 10).

The highest values of uniaxial compressive strength (156-200 MPa) were obtained for dolosparite with low porosity and permeability (Dsl), while the lowest (77-103 MPa) for dolosparite with high porosity and permeability (Dsh). In the case of sealing dolomicrite (Dms), intermediate $R_{c}$ values (123-144 MPa) were obtained (Fig. 10).
The values of Young's modulus $(E)$ were also variable. For the examined dolomite samples-under uniaxial compression conditions-Young's modulus $E$ varied from 40.4 to $76.2 \mathrm{GPa}$ (Fig. 10). The lowest values (40.4-45.2 GPa) were observed for dolosparite with high porosity and permeability (Dsh). The highest values, 42.9-76.2 GPa and 50.3-61.8, were obtained, respectively, for dolosparite with low porosity and permeability (Dsl) and sealing dolomicrite (Dms).

Smaller differences were obtained for the values of Poisson's ratio under uniaxial compression conditions (Fig. 10). The highest $v$ values $(0.23-0.31)$ were observed for dolosparite with low porosity and permeability (Dsl), intermediate ones (0.22-0.29) for sealing dolomicrite (Dms), and the lowest $(0.24-0.26)$ for dolosparite with high porosity and permeability (Dsh). It should be noted that the maximum values in the variability ranges for the three different dolomite facies were much more variable than the minimum values.

Strain-stress curves obtained from uniaxial strength tests (Fig. 11) indicate that increase of porosity in the dolomite causes decrease of the vertical (stress) and horizontal (strain) ranges of the curves and their shapes. Increase of dolomite porosity causes decrease of uniaxial compressive strength, deformability, dip of the strain-stress curve, Young's modulus, and Poisson's ratio.

The values of stresses at the threshold of proper dilatancy in absolute values in $\mathrm{MPa}\left(\sigma_{D}\right)$ and normalized values in relation to the maximum stress $\left(\sigma_{D} / \sigma_{\max }\right)$ are also variable depending on the dolomite facies (Table 4) (cf. Łukaszewski 2007). The threshold of proper dilatancy for dolosparite with high porosity and permeability (Dsh) is above $65 \%$ of the maximum stress, while the threshold of proper dilatancy for dolosparite with low porosity and permeability (Dsl) and sealing dolomicrite (Dms) is $43-60 \%$ of the maximum stress.

\section{Triaxial compressive strength}

The results of the triaxial compressive strength tests showed a similar variability of strength and strain properties for the particular dolomite facies as in the uniaxial compressive strength tests (Fig. 12). The highest differential stress (269-291 MPa) was obtained for dolosparite with low porosity and permeability (Dsl), intermediate (234 MPa) for sealing dolomicrite (Dms), while the lowest (156 MPa) for dolosparite with high porosity and permeability (Dsh).

Large differences between the dolomite facies were also observed for Young's modulus obtained in triaxial compression conditions (Fig. 12). The highest values (59-64 GPa) were obtained for dolosparite with low porosity and permeability (Dsl), intermediate (59 GPa) for sealing dolomicrite 

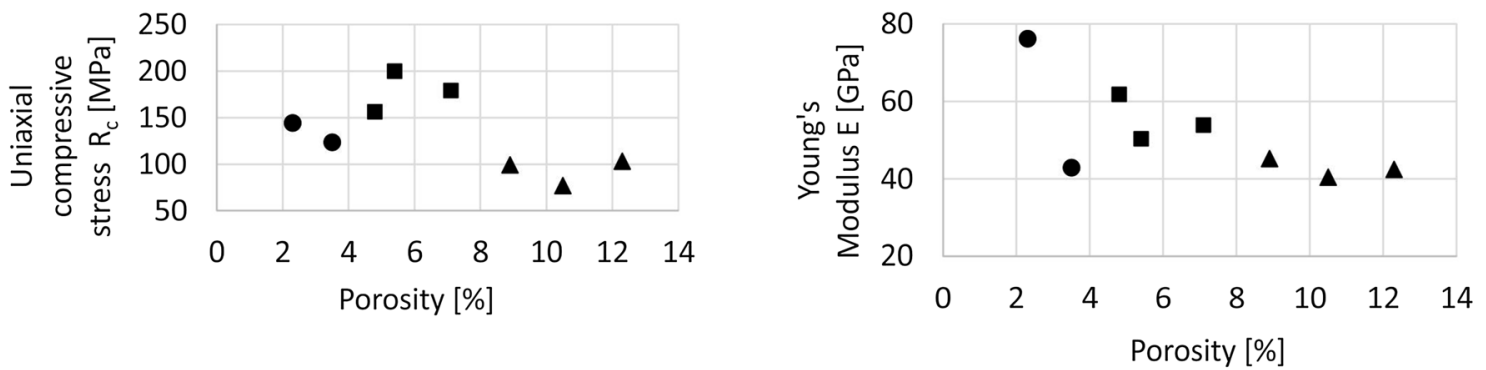

\ Dolosparite with high reservoir properties (Dsh)

- Dolosparite with low reservoir properties (Dsl)

- Sealing dolomicrite (Dms)

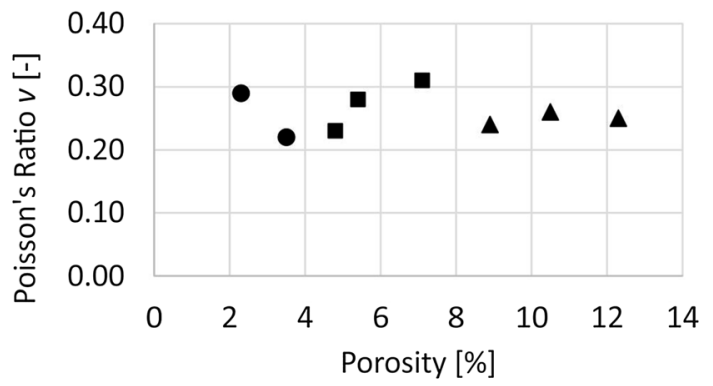

Fig.10 Relation between porosity and geomechanical parameters from uniaxial compressive strength tests

Fig. 11 Axial stress vs. strain from uniaxial compressive strength tests

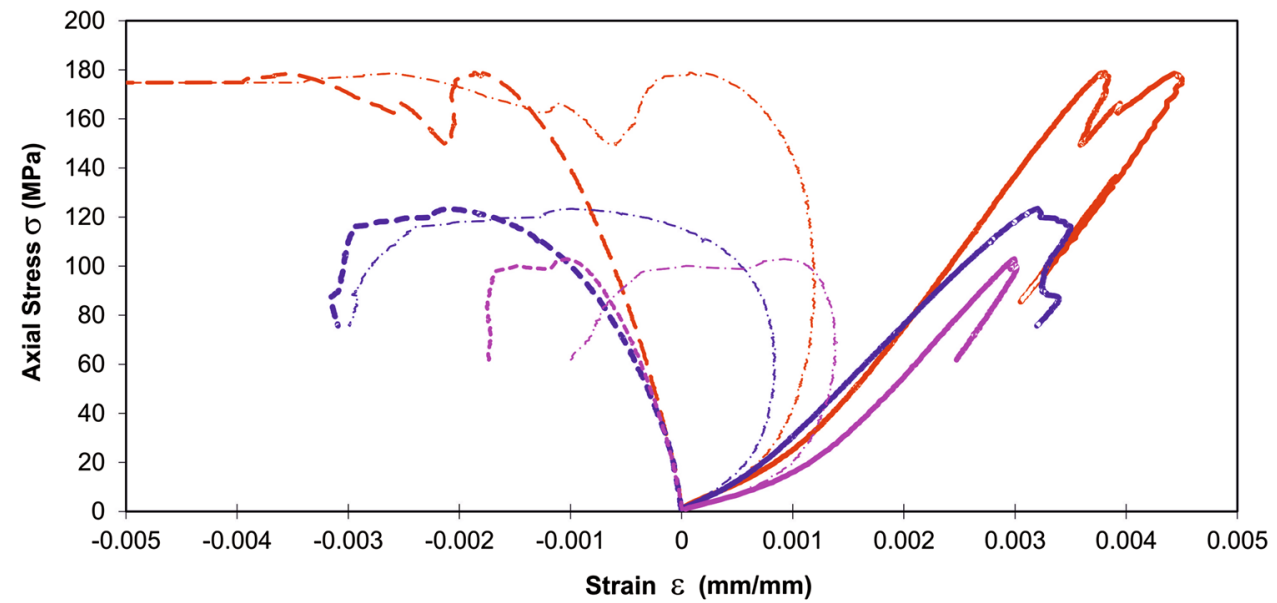

Dsl - axial strain Dms - axial strain - -Dsl - lateral strain $-\infty$ Dms - lateral strain
-. - Dsl - volumetric strain -. Dms - volumetric strain -. - Dsh - volumetric strain

Table 4 Results from uniaxial compressive strength tests

\begin{tabular}{|c|c|c|c|c|c|}
\hline Dolomite facies & $\begin{array}{l}\text { Uniaxial compressive stress } \\
R_{c}=\sigma_{\max }[\mathrm{MPa}]\end{array}$ & $\begin{array}{l}\text { Young's modulus } \\
\text { E [GPa] }\end{array}$ & $\begin{array}{l}\text { Poisson's ratio } \\
\nu[-]\end{array}$ & $\begin{array}{l}\sigma_{D} \\
{[\mathrm{MPa}]}\end{array}$ & $\begin{array}{l}\sigma_{D} / \sigma_{\max } \\
{[\%]}\end{array}$ \\
\hline \multirow[t]{3}{*}{ Dolosparite with high reservoir properties (Dsh) } & 103 & 42.4 & 0.250 & 69 & 76 \\
\hline & 77 & 40.4 & 0.260 & 50 & 65 \\
\hline & 99 & 45.2 & 0.240 & 69 & 70 \\
\hline \multirow[t]{3}{*}{ Dolosparite with low reservoir properties (Dsl) } & 200 & 50.3 & 0.280 & 86 & 43 \\
\hline & 156 & 61.8 & 0.230 & 93 & 60 \\
\hline & 179 & 53.9 & 0.310 & 94 & 53 \\
\hline \multirow[t]{2}{*}{ Sealing dolomicrite (Dms) } & 144 & 76.2 & 0.290 & 78 & 54 \\
\hline & 123 & 42.9 & 0.220 & 65 & 53 \\
\hline
\end{tabular}



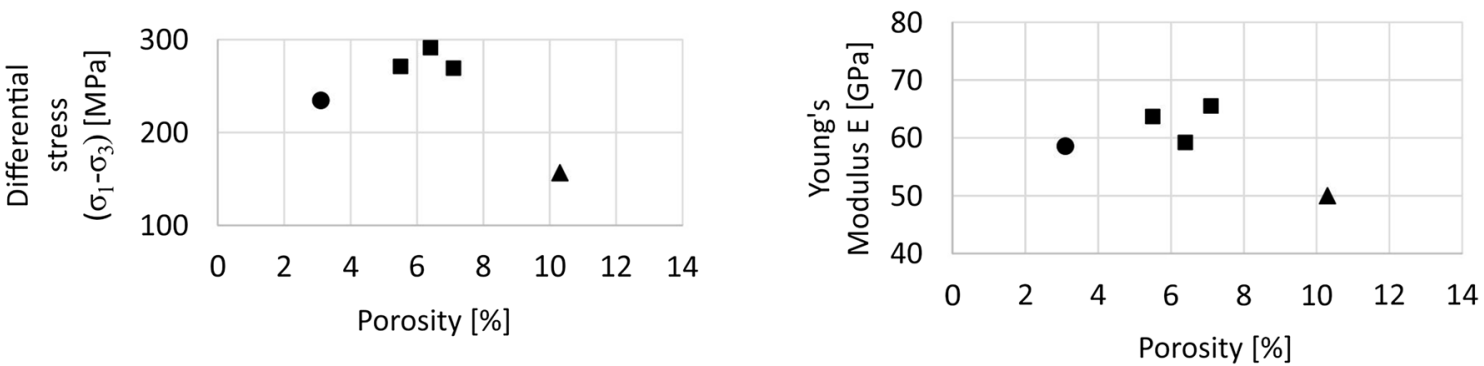

$\Delta$ Dolosparite with high reservoir properties (Dsh)

- Dolosparite with low reservoir properties (Dsl)

- Sealing dolomicrite (Dms)

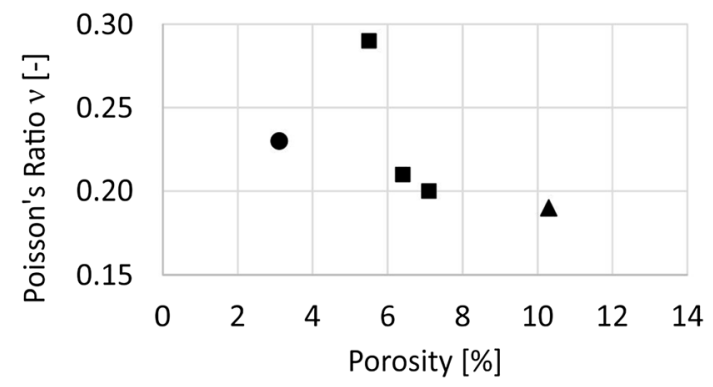

Fig. 12 Relation between porosity and geomechanical parameters from triaxial compressive strength tests related to dolomite facies with different reservoir properties

(Dms), and the lowest (50 GPa) for dolosparite with high porosity and permeability (Dsh).

Much smaller differences were observed for the values of Poisson's ratio determined under triaxial compression conditions (Fig. 12). Again, the highest values (0.2-0.29) were obtained for dolosparite with low porosity and permeability (Dsl), and the lowest (0.19) for dolosparite with high porosity and permeability (Dsh). An intermediate value of 0.23 was obtained for sealing dolomicrite (Dms).
The dolomite facies are characterized by a similar deformation path; however, values of differential stress are variable (Fig. 13). Stresses for proper dilatancy are also variable depending on the dolomite facies (Table 5). The threshold of proper dilatancy for dolosparite with high porosity and permeability (Dsh) is $100 \%$ of the maximum stress, while the threshold of proper dilatancy for dolosparite with low porosity and permeability (Dsl) and sealing dolomicrite (Dms) is $54-74 \%$ of the total stress.
Fig.13 Differential stress vs. strain from triaxial compressive strength tests related lo dolomite facies with different reservoir properties

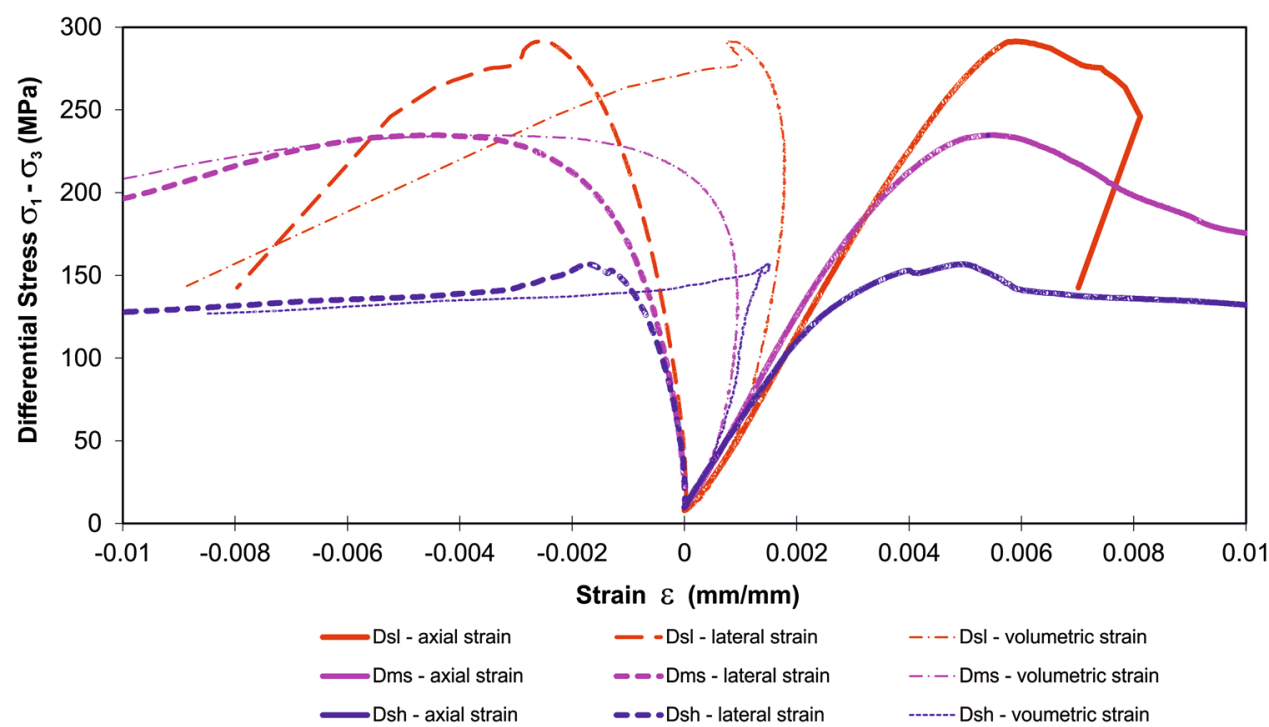


Table 5 Results from triaxial compressive strength tests

\begin{tabular}{|c|c|c|c|c|c|c|}
\hline \multirow[t]{2}{*}{ Petrophysical facies } & Differential stress & Young's modulus & Poisson's ratio & $\left(\sigma_{1}-\sigma_{3}\right)_{D}$ & $\begin{array}{l}\left(\sigma_{1}-\sigma_{3}\right)_{D} / \\
\left(\sigma_{1}-\sigma_{3}\right)_{\max }\end{array}$ & Porosity \\
\hline & $\left(\sigma_{1}-\sigma_{3}\right)_{\max }[\mathrm{MPa}]$ & $\mathrm{E}[\mathrm{GPa}]$ & $\nu[-]$ & {$[\mathrm{MPa}]$} & {$[\%]$} & {$[\%]$} \\
\hline Dolosparite with high reservoir properties (Dsh) & 156 & 50.0 & 0.19 & & 100 & 10.3 \\
\hline \multirow[t]{3}{*}{ Dolosparite with low reservoir properties (Dsl) } & 291 & 59.2 & 0.21 & 215 & 74 & 6.4 \\
\hline & 271 & 63.8 & 0.29 & 145 & 54 & 5.5 \\
\hline & 269 & 65.5 & 0.20 & 178 & 66 & 7.1 \\
\hline Sealing dolomicrite (Dms) & 234 & 58.6 & 0.23 & 128 & 55 & 3.1 \\
\hline
\end{tabular}

\section{Failure pattern}

\section{Dolomite after tensile (indirect) strength}

The tested rocks show penetrative failure within each dolomite facies. The failure resulted in the formation of the widest damage zone within dolosparite with high porosity and permeability (Dsh), reaching $22 \mathrm{~mm}$ (Fig. 14a). The damage zone reaches $16 \mathrm{~mm}$ within dolosparite with low porosity and permeability (Dsl) and it is localized as single or double open fractures within sealing dolomicrite (Dms) (Fig. 14b, c). The damage zone of dolosparite with high porosity and permeability (Dsh) comprises a network of interconnected open fractures, while the damage zone of dolosparite with low porosity and permeability (Dsl) comprises a set of open fractures. Spacing of the fractures reaches up to several millimeters in the central part of the sample and becomes denser towards the outer part of the sample on both sides. The fractures cut the dolomite independently of their textural heterogeneities. They show various traces, from curved and irregular (dolosparite with high-porosity and -permeability Dsh, dolosparite with low-porosity and -permeability Dsl) to almost straight (dolosparite with low-porosity and -permeability Dsl, sealing dolomicrite Dms).

\section{Dolomite after uniaxial compressive strength tests}

Dolomite after uniaxial compressive strength tests shows the presence of individual shear fractures or sets of shear fractures (Fig. 15a-c) variously distributed within dolosparite with high porosity and permeability (Dsh), dolosparite with low porosity and permeability (Dsl) and sealing dolomicrite (Dms). Traces of fractures are irregular. They tend to refract or die out at textural heterogeneities, e.g., larger grains of anhydrite.

Failure of dolosparite with high porosity and permeability (Dsh) resulted in the formation of individual shear fractures at $\sim 30^{\circ}$ to $40^{\circ}$ with respect to the major principal stress $\sigma_{1}$ (Fig. 15a). The induced shear fractures show various development, from gentle, almost difficult to trace, to distinct with a visible tendency for displacement. They show irregular branches and oversteps of segments that resulted in the formation of isolated lenses. Occasionally, the induced shear fractures are aligned by thin, irregularly distributed white
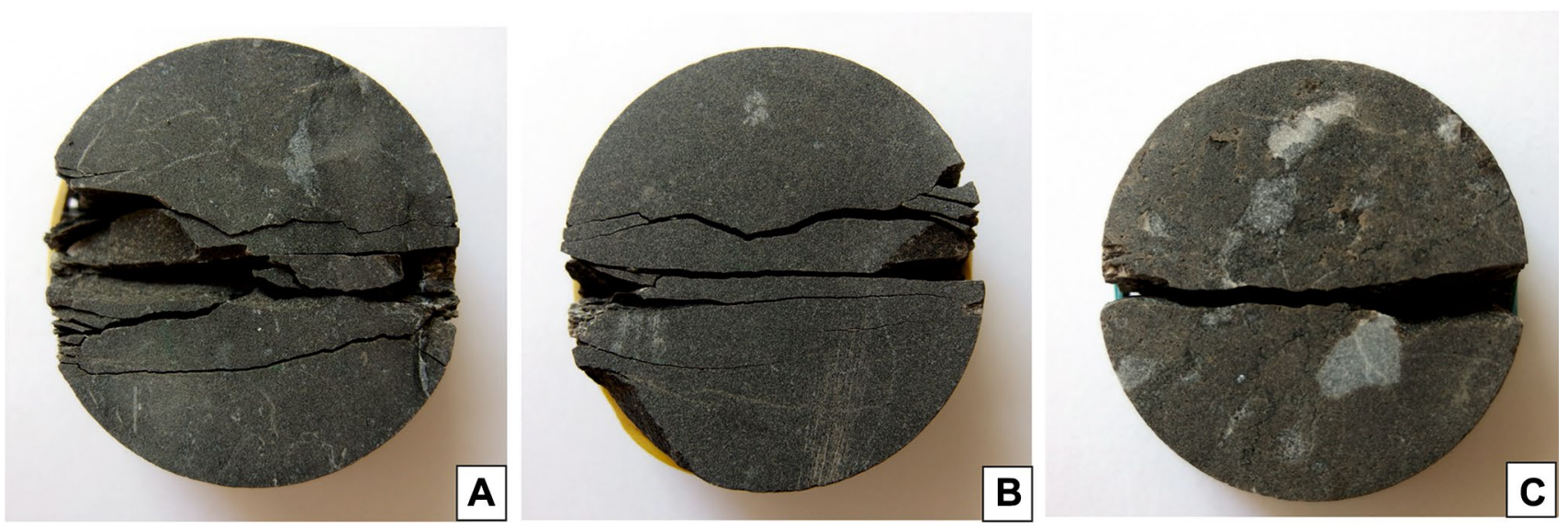

Fig.14 Examples of dolomite samples after tensile strength tests within dolomite facies with different reservoir properties: a dolosparite with high reservoir properties (Dsh); b dolosparite with low reservoir properties (Dsl); c sealing dolomicrite (Oms) 
Fig. 15 Shear fractures induced by uniaxial compressive tests: a shear fractures within dolosparite with high reservoir properties (Dsh); $\mathbf{b}$ dense set of shear fractures within dolosparite with tow reservoir properties (Dst) with subsidiary $(R)$ shear fractures; $\mathbf{c}$ shear fracture within sealing dolomicrite (Oms). Arrows show sense of movement along the shear fractures
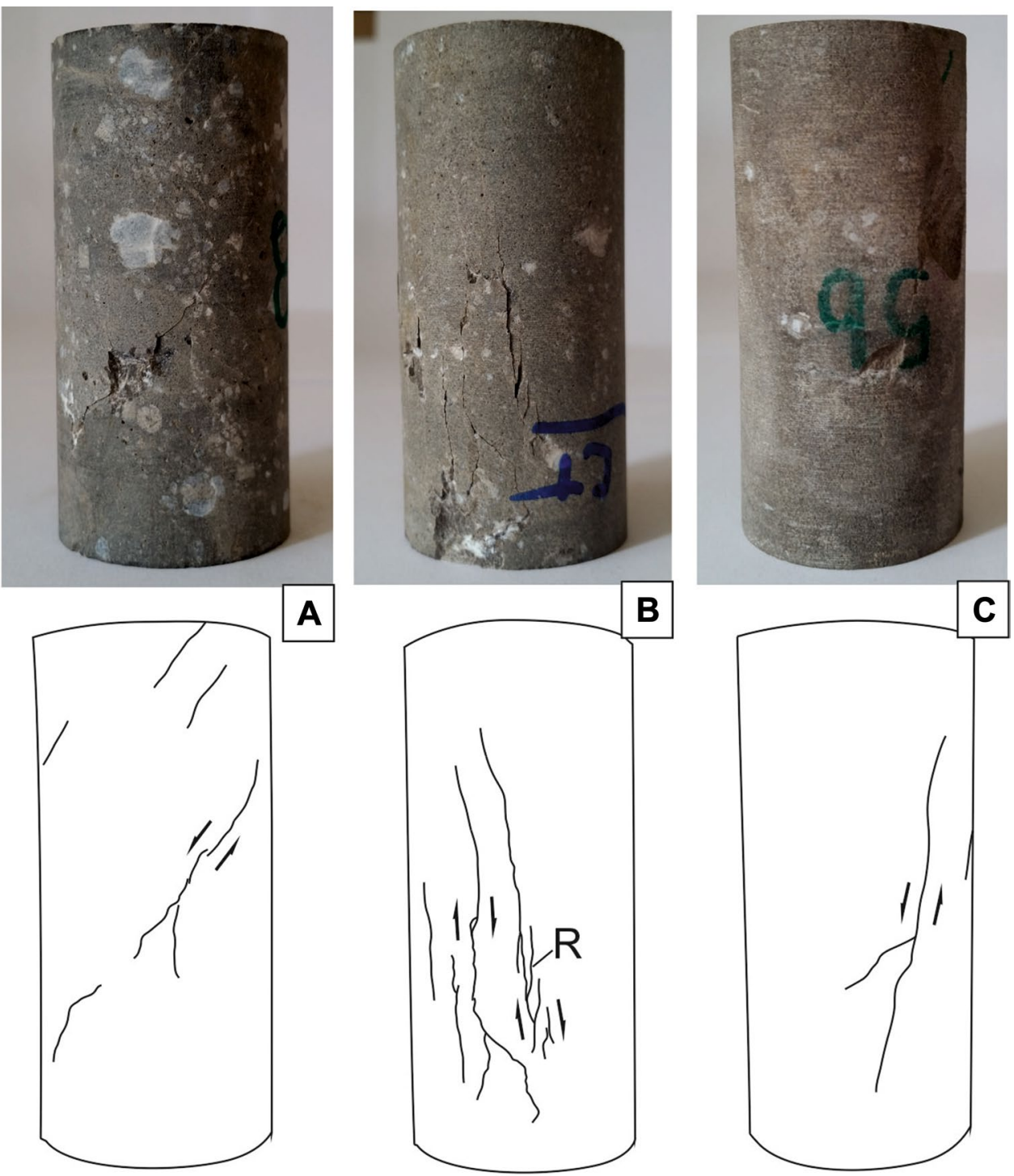

fault rocks that macroscopically can be defined as gouge (cf. Sibson 1977; Woodcock and Mort 2008).

Dolosparite with low porosity and permeability (Dsl) comprises distinct shear fractures at $\sim 10^{\circ}$ with respect to the major principal stress $\sigma 1$ that are arranged in sets of a wide range (Fig. 15b). The fractures rarely continue along the whole sample and locally show an en echelon arrangement. Damage zones show subsidiary shear fractures-their geometrical relation to the main shear fractures suggests that they correspond to R shear fractures (Riedel 1929).

Sealing dolomicrite (Dms) comprises individual sets of shear fractures at $\sim 10^{\circ}$ with respect to the major principal stress $\sigma_{1}$ (Fig. $15 \mathrm{c}$ ). They continue along the core samples as arrays of segments with oversteps of up to $1.5 \mathrm{~cm}$ in size.

Thin-section analysis confirms the shear component along the fractures (Fig. 16) that shows segmented, irregular traces with an overstepping geometry. The apertures of the shear fractures reach up to $0.01 \mathrm{~mm}$. They show the presence of fractured and comminuted mineral grains that can be classified as cataclastic rocks (e.g., Aydin 1978; Aydin and Johnson 1983). The thickness of cataclastic rocks reaches $0.006 \mathrm{~mm}$. The presence of subsidiary Riedel shears along the shear fractures and their overstepping geometry along with the grain size reduction within the fault rocks in relation to the host rocks allow to define them as shear cataclastic bands (after Aydin et al. 2006).

\section{Dolomite after triaxial compressive strength tests}

Rock samples after triaxial compressive strength tests show the presence of small-scale normal faults and shear fractures at $25^{\circ}-30^{\circ}$ with respect to the major principal stress $\sigma_{1}$. They are arranged in complementary conjugate systems composed of two sets of opposite dips that form an acute angle ranging from $40^{\circ}$ to $50^{\circ}$ (Fig. 17a-c). Dolosparite shows systems of normal faults with one predominant set that is present in 

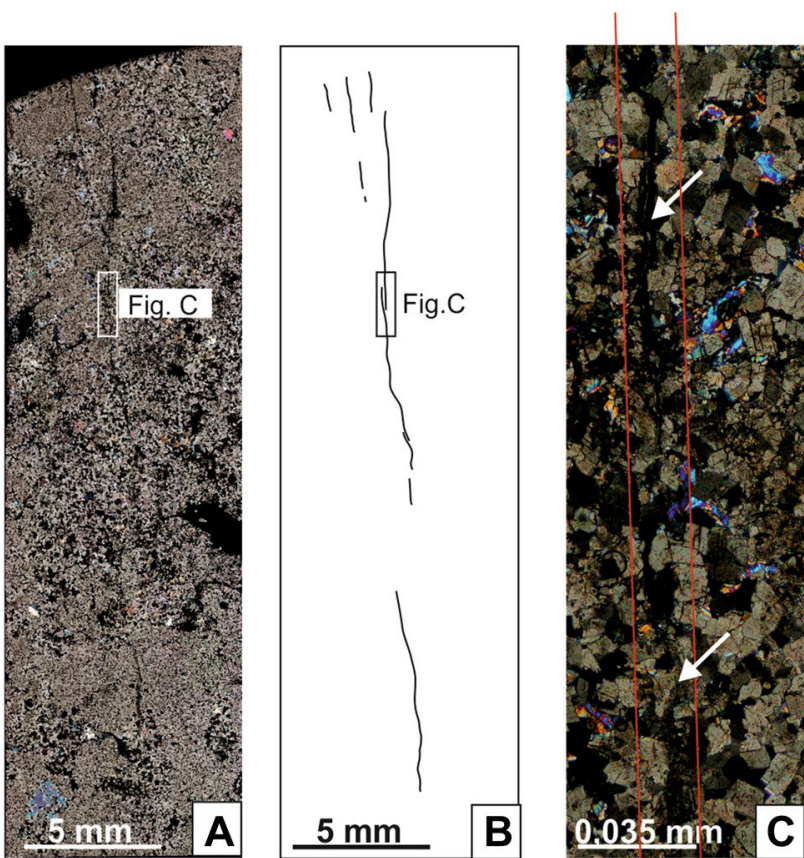

Fig. 16 Details of fracture propagation and failure of grains within compactive shear band nucleated within dolosparite with high reservoir properties (Dsh): a, b discontinuous trace of the shear fracture with local overstepping geometry; c cataclastic disintegration of grains along the fracture (lower part). The disintegrated grains have been partly mechanically lost during thin section preparation (central and upper parts) all samples and a second set that is less distinct (Fig. 17a, b), while dolomicrite shows a system of variously distributed shear fractures arranged in a dense network (Fig. 17c). Traces of induced structures within all dolomite facies are irregular, continuous or segmented, arranged in en echelon arrays. Contractional overstepping geometry of the segments resulted in the formation of a lensoidal or rhomboidal geometry. The widely spread anhydrite assemblages of various size were encompassed or cut through by induced structures with a slight refraction of their traces (Fig. 17c).

Damage zones of induced faults within dolosparite with high porosity and permeability (Dsh) and dolosparite with low porosity and permeability (Dsl) show individual subsidiary shear fractures classified as R shears (after Riedel 1929). Damage zones of induced shear fractures within sealing dolomicrite (Dms) are weakly developed-failure of the host rock is defined rather by a dense network of shear fractures than the formation of associated subsidiary structures.

Rock samples after triaxial compressive strength tests show the presence of small-scale normal faults and shear fractures that are arranged in sets or systems. Systems of normal faults comprise complementary conjugate shear fractures that form an acute angle ranging from $40^{\circ}$ to $50^{\circ}$ (Fig. 17b, c).

Macroscopic analysis of induced fault and shear fracture networks in all samples revealed the presence of very thin zones of fine-grained gouge along them. The gouge thickness changes within dolomite samples-it is related to the amount of displacement along the faults and shear fractures. The faults developed within dolosparite with high porosity and permeability (Dsh) show a displacement of up to $1 \mathrm{~mm}$ and within dolosparite with low porosity and permeability
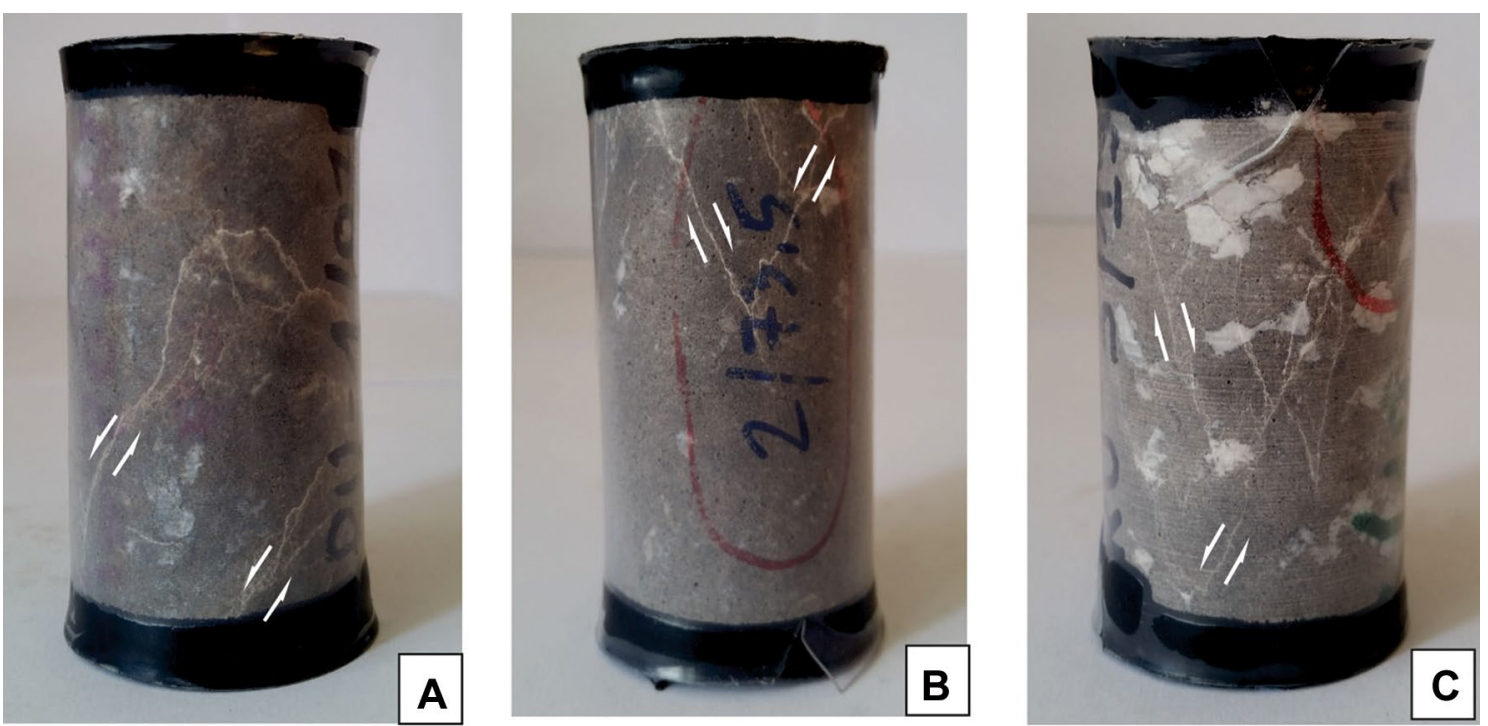

Fig. 17 Small-scale faults and shear fractures induced by triaxial tests within: a dolosparite with high reservoir properties (Dsh); b, c dolosparite with low reservoir properties (Dsl); c sealing dolomicrite
(Oms). Arrows show the sense of movement along the small-scale faults and shear fractures 
(Dsl) — up to $0.6 \mathrm{~mm}$ - while the shear fractures within sealing dolomicrite (Dms) show rather a tendency for displacement that is scarcely visible in a hand sample.

Thin sections indicate that the displacement along the faults within dolosparite with high porosity and permeability (Dsh), dolosparite with low porosity and permeability (Dsl) and sealing dolomicrite (Dms) resulted in fracturing and comminution of the host rock mineral grains and formation of cataclastic shear bands (Fig. 18a-c). The thickness of the cataclastic shear bands differs within samples from up to $0.012 \mathrm{~mm}$ within dolosparite with high porosity and permeability (Dsh), through up to $0.003 \mathrm{~mm}$ within dolosparite with low porosity and permeability (Dsl) to $0.002 \mathrm{~mm}$ within sealing dolomicrite (Dms) (Fig. 18a-c), which is consistent with the amount of displacement along the faults and shear fractures.

\section{Discussion}

The dolomite facies from the gas reservoir horizon are characterized by different textures, porosity, reservoir and geomechanical properties, and failure patterns (Table 6). The results are discussed with regard to the influence of dolomite texture and porosity on their failure, the mechanism of different dolomite facies failure, and the gas trap stability during mining operations.

\section{Influence of dolomite texture and porosity on their failure}

Macro- and microstructural observations of failure within the dolomite samples confirm the dependence of dolomite failure on its porosity and texture (Figs. 14, 15, 17, 18), similarly as in other carbonate rocks (cf. Cilona et al. 2012; Bullock et al. 2016; Rybak-Ostrowska et al. 2017).

The failure pattern of dolomite resulting from uniaxial indirect tensile strength tests indicates a variable distribution of failure in relation to the texture and porosity of the dolomite facies defined by the decreasing width of the damage zones and related decreasing density of fractures within damage zones from Dsh through Dsl to Dms (Fig. 14a-c). The formation of interconnected open fractures within damage zones of Dsh and Dls may have relevant influence on the increase of permeability of Dsh and Dsl after failure. Additionally, the formation of open fractures within damage
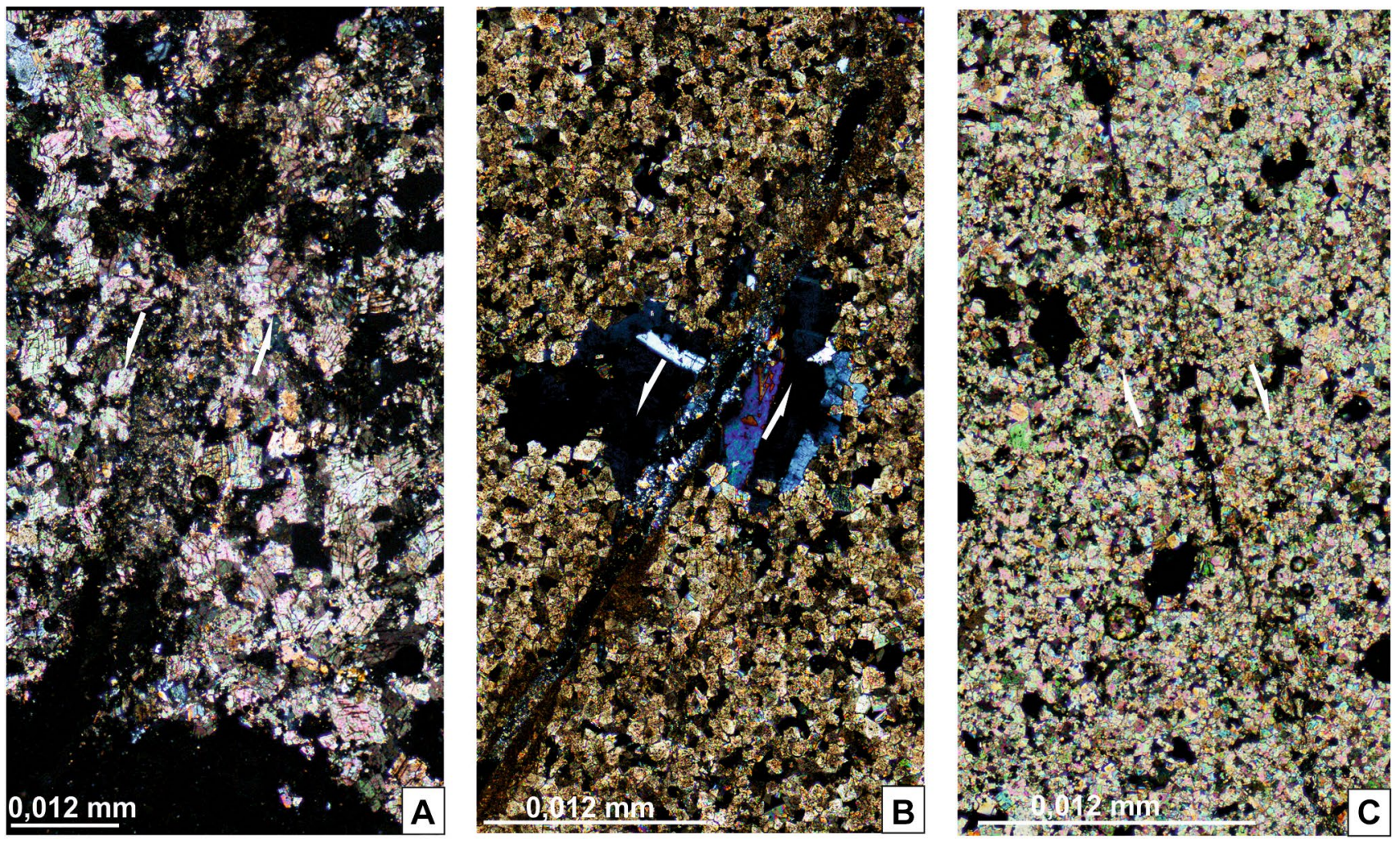

Fig. 18 Small-scale faults and shear fractures induced during triaxial tests: a, b fine-grained cataclastic shear bands within host dolomite: Dsh and Dsl petrophysical facies, respectively; the comminution affects all host grains including anhydrite patches (b); c narrow zone of slightly fractured host rock grains along a shear fracture within the petrophysical facies Oms. Arrows show the sense of movement along the faults and shear fractures 
Table 6 Summarized list of results

\begin{tabular}{|c|c|c|c|}
\hline Analysis & Samples: 1, 7(a), 7(b), 8, 11 & Samples: $3,9,12,13$ & Samples: $2,4,5,6,10$ \\
\hline Dolomite texture & Sparite & Sparite & Micrite \\
\hline Dominant diagenetic features & Intensive dissolution & Intensive cementation & Lack of dissolution \\
\hline Effective porosity [\%] & 5 & 6 & 0.2 \\
\hline Permeability [mD] & 3.25 & 0.06 & 0 \\
\hline Dolomite facies & Dsh & Dsl & Dms \\
\hline \multicolumn{4}{|l|}{ Tensile strength tests } \\
\hline $\begin{array}{l}\text { Microscopy porosity before tests } \\
\text { [\%] }\end{array}$ & $8.9-12.3$ & $4.8-7.1$ & $2.3-3.5$ \\
\hline Indirect Tensile & $7-10$ & $12-17$ & $11-13$ \\
\hline Dominant failure pattern & $\begin{array}{l}\text { Network of open interconnected } \\
\text { fractures (width of damage zone } \\
\text { up to } 22 \mathrm{~mm} \text { ) }\end{array}$ & $\begin{array}{l}\text { Set of open fractures (width of } \\
\text { damage zone up to } 16 \mathrm{~mm} \text { ) }\end{array}$ & $\begin{array}{l}\text { Individual or double open fractures } \\
\text { (width of damage zone up to } \\
8 \mathrm{~mm} \text { ) }\end{array}$ \\
\hline \multicolumn{4}{|l|}{ Uniaxial compressive strength tests } \\
\hline $\begin{array}{l}\text { Microscopy porosity before tests } \\
\text { [\%] }\end{array}$ & $8.9-12.3$ & $4.8-7.1$ & $2.3-3.5$ \\
\hline MCT porosity before tests [\%] & 1.4 & 1.13 & 0.63 \\
\hline MCT porosity after tests [\%] & 1.12 & 0.5 & 0.9 \\
\hline $\begin{array}{l}\text { Uniaxial compressive stress } \\
\text { [MPa] }\end{array}$ & $77-103$ & $156-200$ & $123-144$ \\
\hline Young's modulus [GPa] & $40.4-45.2$ & $50.3-61.8$ & $42.9-76.2$ \\
\hline Poisson's ratio $[-]$ & $0.240-0.260$ & $0.230-0.310$ & $0.220-0.290$ \\
\hline Proper dilatancy [\%] & $65-70$ & $43-60$ & $53-54$ \\
\hline Dominant failure pattern & Individual shear fractures & Set of shear fractures & Set of shear fractures \\
\hline \multicolumn{4}{|l|}{ Triaxial compressive strength tests } \\
\hline $\begin{array}{l}\text { Microscopy porosity before tests } \\
{[\%]}\end{array}$ & 10.3 & $5.5-7.1$ & 3.1 \\
\hline MCT porosity before tests [\%] & 4.71 & 1.87 & 0.63 \\
\hline MCT porosity after tests [\%] & 0.42 & 1.15 & 1.28 \\
\hline Differential Stress [MPa] & 156 & $269-291$ & 234 \\
\hline Young's modulus [GPa] & 50.0 & $59.2-65.5$ & 58.6 \\
\hline Poisson's ratio $[-]$ & 0.19 & $0.20-0.29$ & 0.23 \\
\hline Proper dilatancy [\%] & 100 & $54-74$ & 55 \\
\hline Dominant failure pattern & Set of microfaults cataclasis & $\begin{array}{l}\text { System of conjugate microfaults } \\
\text { cataclasis }\end{array}$ & $\begin{array}{l}\text { Dense system of conjugate shear } \\
\text { fractures weak cataclasis }\end{array}$ \\
\hline
\end{tabular}

zones of Dms may create effective porosity by connecting isolated pores within this rock. Correlating the results of uniaxial indirect tensile tests with excavation procedures in the Rudna Copper Mine, we suggest that drilling within Dms may liberate gas from the isolated pores and enhance its migration through induced fractures toward Dsh and Dsl. Moreover, drilling within Dsh and Dsl may provide additional pathways for gas migration.

The trend is also present in the results of uniaxial and triaxial compressive strength tests (Figs. 11, 13). However, they show the formation of cataclastic bands during failure of the dolomite facies (Fig. 16a, c). Dolomite with high porosity and permeability (Dsh) is characterized by the lowest uniaxial and triaxial compressive strength (Fig. 13), due to high porosity and large size of pores (Fig. 4). Dolomite with low porosity and permeability (Dsl) reveals the predomination of cementation over dissolution during diagenesis (Poszytek et al. 2018); hence, the pores are smaller $(<50 \mu \mathrm{m})$ than the pores in dolomite with high porosity and permeability (Dsh) (Fig. 4d-f). Low porosity of that facies may be correlated with the highest uniaxial and triaxial compressive strength (Figs. 10, 12).

The failure pattern of dolomite resulting from triaxial compressive strength tests indicates that porosity and texture of individual facies controlled the thickness, geometry and density of induced cataclastic bands, as well as displacement along them (Figs. 17a-c, 18a-c). Macroscopic observations indicate a trend of increasing density of cataclastic bands 
within sets from Dsh through Dsl to Dms, with a switch from formation of one set of bands within Dsh to the system of conjugate bands within Dsl and Dms (Fig. 17a-c). While microscopic observations indicate decreasing displacement, the thickness and intensity of grain comminution of cataclastic bands from Dsh through Dsl to Dms are defined by decreasing porosity within facies, respectively (Tables 2, 3).

Results of microscopic observations indicate that the most important processes that created dolomite porosity included late diagenetic dissolution and later dolomite cementation (Fig. 4). Dolomite with high porosity and permeability (Dsh) was subject to the most intense dissolution, after which pores were partly cemented by dolomite (Fig. 4). Hence, large sizes of pores are visible on the plot of pore distribution ( $>100 \mu \mathrm{m}-$ Fig. 4c). These large pores correspond to vugs partly cemented by euhedral dolomite crystals (Fig. 4a).

Sealing dolomicrite (Dms) underwent weak dissolution, a fact that was caused by low permeability that impeded access for migrating waters (Poszytek et al. 2018). Hence, pores of Dms are small, not connected and dispersed in the rock fabric (Fig. 4d-f)-which is typical for dolomicrite (Lucia 2007). Based on recent studies (e.g., Akram et al. 2017; Sabatakakis et al. 2008) one may expect that the fabric of dolomicrite could have predestinated this rock to higher uniaxial and triaxial compressive strength than dolosparite. By contrast, results of geomechanical tests evidence intermediate uniaxial and triaxial compressive strength of sealing dolomicrite Dms (Figs. 11, 13). Correlating these results with porosity and occurrence of late diagenetic dolomite cements in the dolosparite facies, we assume that most probably the occurrence of these cements may have had impact on dolosparite strength. Thus, the highest strength of dolosparite with low porosity and permeability (Dsl) is related to the high volume of late diagenetic dolomite cements. The lowest strength of dolomite with high porosity and permeability (Dsh) is related to the low volume of late diagenetic dolomite cements.

In conclusion, the occurrence of dolomite facies with different petrophysical properties in the rock mass is determined by the extent of late diagenetic dolomite cements. Probably the dolomite facies occur as a mosaic with blurred and gradual boundaries between their different types. Such mosaic nature of the reservoir horizon results in reservoir and geomechanical barriers (dolosparite with low porosity and permeability and sealing dolomicrite) for gas migration and damage propagation.

\section{Mechanism of dolomite damage}

Results of experimental research (Figs. 9, 11, 13) indicate that the development of brittle deformation depends on dolomite texture and porosity (cf. Wong and Baud 2012).
Laboratory and theoretical studies (Kemeny and Cook 1991; Zhu et al. 2011; Vajdova et al. 2012) show that pores and preexisting cracks within rocks are potential places for tensile stress concentration and microfracture initiation during laboratory tests. Pore collapse and subsequent cataclasis on their borders play a crucial role in porous rocks (Vajdova et al. 2010, 2012). This process is described by the micromechanical pore-emanated cracking model of Sammis and Ashby (1986). Conversely, preexisting cracks play a crucial role in low-porosity rocks. Further development of microcracks in porous and non-porous rocks is compatible with the sliding wing crack model of Ashby and Sammis (1990). Based on these models, we conclude that the development of microcracks within dolomite caused primary dilatancy and strain hardening (Figs. 9, 11, 13). The secondary, more pervasive damage of the dolomite is related to the progressive connection of microcracks that resulted in the formation of small-scale fractures and faults (Figs. 14, 15, 17).

Porosity reduction of dolosparite with high porosity and permeability (Dsh) and dolosparite with low porosity and permeability (Dsl), and porosity increase of sealing dolomicrite (Dms) after geomechanical tests (Figs. 5, 6, 7) indicate that dolomite with higher porosity shows a tendency to a non-elastic compaction and shear enhanced cataclasis, while dolomicrite with low porosity shows a tendency to dilatancy, similarly as limestones (cf. Fredrich et al. 1989; Baud et al. 2000 ; Vajdova et al. 2004, 2010). The macrodilatancy threshold for dolomite with high porosity and permeability is higher (Dsh) than for dolomite with low porosity (Dsl and Dms) (Tables 4, 5 ), which indicates different models of brittle deformation in dolomite with varying porosity (e.g., Vajdova et al. 2012).

Field and laboratory studies indicate that the cataclastic failure of porous rocks within deformation bands reduces porosity and permeability (e.g., Aydin and Johnson 1978; Knipe et al. 1997; Hesthammer and Fossen 2000; Fisher and Knipe 2001; Shipton et al. 2002; Fossen et al. 2007). However, recent studies indicate that the capability of deformation bands to form barriers against fluid flow depends on the degree of cataclasis along with spatial distribution and thickness of bands within the host rocks (e.g., Rotevatn et al. 2009; Ballas et al. 2012, 2015; Soliva et al. 2013). Analogically, we interpret that the induced cataclastic failure of grains reduced dolomite porosity within deformation bands with the weakest comminution of grains in Dms. At the same time, failure of Dms resulted in denser distribution of bands. Thus, the induced cataclastic deformation bands may be potential capillary seals (e.g., Antonellini and Aydin 1994) that may impede and/or reduce gas migration within dolomites. Moreover, the induced network of low-permeable cataclastic deformation bands may result in compartmentalization of the gas reservoir horizon similarly as in clastic hydrocarbon reservoirs (Leveille et al. 1997; Al-Hinaï et al. 2008; Tueckmantel et al. 2012). 
As a consequence, the reduction of porosity within cataclastic deformation bands may induce gas liberation and its migration into induced small-scale compartments. This process may result in the increase of gas pressure within individual compartments. The compartmentalization of the samples defined by the network of deformation bands with increasing density from Dsh through Dsl to Dms suggests that the Dsl and Dms facies may provide the most overpressured compartments. Coupling these interpretations with the results of indirect tensile strength tests, we suggest that the formation of cataclastic bands may liberate gas from the Dsh and Dsl into induced zones of interconnected fractures. At the same time, gas trapped in isolated pores within Dsl and Dms may be partly released; however, the network of deformation bands may create additional barriers for flow and result in gas pressure build-up within local small-scale compartments. This is, however, a subject that requires further studies.

The presented results suggest that dolosparite with high porosity and permeability (Dsh) may be the most degassed medium by failure of pores and release of gas through the induced network of fractures. This interpretation is confirmed by decrease in porosity of Dsh at $60 \%$ and $90 \%$ during uniaxial and triaxial strength tests, respectively (Figs. 6, 7). As a result, at least $10 \%$ from primary porosity may remain intact within the Dsh.

Dolosparite with low porosity and permeability (Dsl) may be only partly degassed during and after failure. The remaining part of pores that did not fail (Figs. 6f, 7f) may still contain gas. Gas released from failed pores within Dsh and Dsl may flow through induced fractures or cumulate along induced cataclastic deformation bands. In effect, both dolosparite facies after failure still contain gas traps.

Gas released from isolated pores in sealing dolomicrite (Dms) could flow to the borehole through new cracks; however, part of the gas could have been accumulated in new pores created by dilatancy-related microcracking (Fig. 6i). The induced porosity may cause permeability increase.

The presented interpretation indicates that total degassing of the rock mass by drilling during mining operations is impossible, because gas traps remain in all dolomite facies.

\section{Influence of mining operations on gas traps}

Mining operations including borehole drilling and excavating change the existing stress field around them (e.g., Zoback 2007). Boreholes drilled in dolomite may cause its damage similar to that observed at the tip of propagating dynamic raptures and immediately behind them (Dor et al. 2006, 2009; Yuan et al. 2011; Doan and d'Hour 2012; Aben et al. 2016; Xu and Ben-Zion 2017). Laboratory experiments indicate that fault propagation is accompanied by intensive development of tensile cracks at the tip of faults (e.g., King and Sammis 1992; Reches and Lockner 1994; Samudrala et al. 2002; Griffith et al. 2009; Ghaffari et al. 2014). An additional effect of fault propagation may be the pulverization of rocks in the front of the propagating tip (e.g., Dor et al. 2006, 2009; Billi and Di Toro 2008; Rempe et al. 2013).

We interpret that mining operations in the Rudna Copper Mine probably change the stress field in the ceiling of the excavations and modify the pore pressure, which results in the differentiation of effective stress. This leads to the damage of dolomite in a low confining pressure environment. Based on the literature data presented above, we suggest that the drilling process could have affected the dolomite in the front of the drill tip by the development of a dense tensile crack network. Subsequent coalescence of cracks might have caused fragmentation of the dolomite. In consequence, the reduced cohesion of dolomite could have induced the rock burst in 2009.

The occurrence of gas within the dolomite is decisive in the initiation of dolomite damage during drilling-causing elevated pore pressure that reduces effective stress leading to dolomite damage (cf. Risnes and Flaageng 1999; Heggheim et al. 2005). In petroleum drilling, gas pressure is controlled by the selection of appropriate parameters of the mud. Properly selected mud controls the borehole surroundings and influences the damage of rocks in the close vicinity of the borehole (Ottesen et al. 1999; Moos et al. 2003; Zoback et al. 2003). However, gas flow is not controlled by mud in boreholes drilled in the ceiling of excavations in underground mines, because mud flows out of the borehole.

Assuming the wave nature of stress propagation in the rock mass (Tarasov et al. 2017), accumulation of stress might have occurred on the boundaries of dolomite facies around the boreholes. Based on this interpretation, we suggest that the mosaic structure of the reservoir horizon causes the occurrence of mechanical boundaries between dolosparite with high porosity and permeability (characterized by low strength) and the other dolomite facies (Dsl and Dms) with higher strength. Hence, dolosparite with high porosity and permeability (Dsh) can be strongly damaged close to the boundary with low-porosity dolomite with higher strength (Fig. 19). The damage of dolomite along the mechanical boundaries of dolomite facies with different petrophysical properties can be delayed; hence, gas flow to the boreholes often varies with time. Some of the drilled boreholes do not produce gas, due to the absence of gas or the strength of dolomite being high enough to withstand the stress around the borehole; as a result, the dolomite remains intact.

Gas leakage to the borehole ends after stabilization of stress and pressure, and depletion of gas resource after damage of the dolomite around the borehole. The dimension of the degassing zone related to the damage area is difficult to 


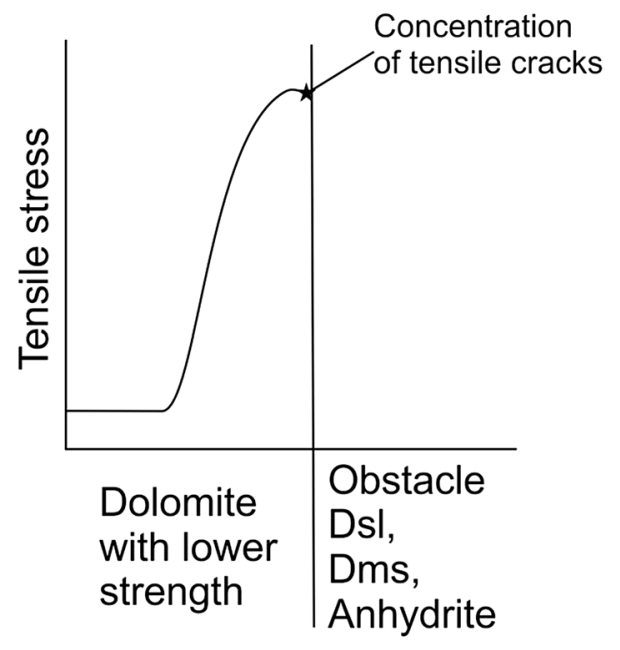

Fig. 19 Scheme of dolomite damage on the boundary with the obstacle (based on Tarasov et al. 2017)

estimate without geophysical logs. However, the 6-m-high cavern that was formed in 2009 after the burst of gas and damage of rocks gives a hint on the scale and magnitude of the process. The cavern was created in the ceiling of a new excavation that was not secured with anchors yet. It caused the change of stress in the ceiling of the excavation. Gas occurring in dolosparite with high porosity and permeability (with low strength) above the new excavation created small stratigraphic traps surrounded by dolosparite with low porosity and permeability and sealing dolomicrite. The occurrence of gas contributing to the stress change resulted in a rapid damage of the gas trap. It created a new stress wave, which propagated through the surrounding dolomite to the boundary with the anhydrite in the top of the Werra dolomite. Stress was accumulated on the dolomite-anhydrite boundary and caused intensive damage of the dolomite, but the anhydrite horizon remained intact. Dolomite fragmentation and high gas pressure resulted in the burst of crushed rocks into the excavation.

Nowadays, copper mines in Poland expand their operations heading towards the north (Fig. 1). There are numerous gas deposits located several dozen kilometers to the north from the limits of the existing copper mines (Karnkowski 1993; Poprawa and Kiersnowski 2010). These gas deposits occur within Rotliegend sandstones and in the Zechstein Limestone. Based on the interpretation presented above, we suggest that the risk of gas ejection can also be expected from the Rotliegend sandstones that occur in the floor of the excavations (Fig. 2). Hence, Rotliegend sandstones in that area should be re-investigated for the hazard of gas ejection that may be related to mining operations.

\section{Conclusions}

Based on the assembled data and available literature, we conclude that the nature of the reservoir horizon in the Rudna Copper Mine is related to its mosaic structure that depends on dolomite texture, extent of late diagenetic dolomite cements, and porosity. These factors determine the petrophysical properties of dolomite facies, mechanical behavior of dolomite facies during laboratory tests along with the induced failure patterns.

The strength of dolomite within the reservoir horizon varies from the highest within dolosparite with low permeability (Dsl) through sealing dolomicrite (Dms) to the lowest within dolosparite with high porosity and permeability (Dsh). We interpret that it is positively correlated with the presence of late diagenetic dolomite cements within dolosparites and the fine texture of dolomicrite. Thus, the mosaic structure of dolomite facies with variable strength produces an anisotropic reservoir horizon.

The induced failure of dolomite facies results in the reduction of their natural porosity. However, all dolomite facies show a tendency for partial preservation of these pores; therefore, they remain as gas traps. Additionally, the failure of sealing dolomicrite (Dms) enhances the development of induced porosity by microcracking. This process may produce new induced traps for gas released from natural pores.

Failure patterns induced within dolomite facies are related to their texture and porosity. The dolomite facies show fracturing during indirect tensile strength tests and formation of cataclastic deformation bands during uniaxial and triaxial strength tests. The induced fractures may create pathways for gas migration, while cataclastic bands may create capillary seals that impede and/or reduce gas migration within and between dolomite facies by the formation of small-scale compartments.

The mosaic nature of the reservoir horizon with blurred and gradual boundaries between its different dolomite facies creates reservoir and geomechanical barriers (dolosparite with low porosity and permeability and sealing dolomicrite) for damage propagation and gas migration during mining operations. The close neighborhood of dolomites with different geomechanical properties may increase the intensity of damage of individual facies. Hence, dolomite with lower strength can be strongly damaged close to the boundary with dolomite with higher strength.

The presented results have significant impact on the assessment of gas traps stability of excavations during mining operations. Future plans for the exploitation of copper deposits in the neighborhood of the existing gas deposits in Poland should give reason for the re-investigation of the Rotliegend sandstone succession in the case of gas trap 
occurrence in the floor of excavations in the Rudna Copper Mine. Moreover, the presented results are the base for planning of underground storage of mineral resources or wastes in closed mines.

Acknowledgements The research was funded by KGHM Polska Miedź SA and the Faculty of Geology, University of Warsaw from Grant no. BSt 176804. The authors would like to thank the staff of the Rudna Copper Mine KGHM Polska Miedź for help in the collection of the samples. Anna Żylińska is thanked for language corrections and Szymon Ostrowski is thanked for inspiring discussions during manuscript preparation. The manuscript greatly benefited from the constructive comments of Prof. Tadeusz Peryt and an anonymous reviewer.

Open Access This article is licensed under a Creative Commons Attribution 4.0 International License, which permits use, sharing, adaptation, distribution and reproduction in any medium or format, as long as you give appropriate credit to the original author(s) and the source, provide a link to the Creative Commons licence, and indicate if changes were made. The images or other third party material in this article are included in the article's Creative Commons licence, unless indicated otherwise in a credit line to the material. If material is not included in the article's Creative Commons licence and your intended use is not permitted by statutory regulation or exceeds the permitted use, you will need to obtain permission directly from the copyright holder. To view a copy of this licence, visit http://creativecommons.org/licenses/by/4.0/.

\section{References}

Aben FM, Doan ML, Mitchell TM, Toussaint R, Reuschlé T, Fondriest M, Gratier JP, Renard F (2016) Dynamic fracturing by successive coseismic loadings leads to pulverization in active fault zones. $\mathbf{J}$ Geophys Res Solid Earth: Solid Earth 121:2338-2360. https://doi. org/10.1002/2015JB012542

Akram MS, Farooq S, Naeem M, Ghazi S (2017) Prediction of mechanical behaviour from mineralogical composition of Sakesar limestone, Central Salt Range, Pakistan. Bull Eng Geol Environ 76:601-615. https://doi.org/10.1007/s10064-016-1002-3

Al-Hinaï S, Fisher QJ, Al-Busafi B, Guise P, Grattoni CA (2008) Laboratory measurements of the relative permeability of cataclastic fault rocks: an important consideration for production simulation modelling. Mar Pet Geol 25:473-485

Antonellini MA, Aydin A (1994) Effect of faulting on fluid flow in sandstones, petrophysical properties. Am Assoc Pet Geol Bull 78:355-377

Ashby MF, Sammis CG (1990) The damage mechanics of brittle solids in compression. Pure Appl Geophys 133:489-521

ASTM D2664-95a (1995) Standard test method for triaxial compressive strength of undrained rock core specimens without pore pressure measurements. ASTM International, West Conshohocken, PA

ASTM D2938-95 (1995) Standard test method for unconfined compressive strength of intact rock core specimens. ASTM International, West Conshohocken, PA

ASTM Designation: D3148-02 (1993) Standard test method for elastic moduli of intact rock core specimens in uniaxial compression. ASTM International, West Conshohocken, PA

Aydin A (1978) Small faults formed as deformation bands in sandstone. Pure Appl Geophys 116:913-930

Aydin A, Johnson AM (1978) Development of faults as zones of deformation bands and as slip surfaces in sandstone. Pure Appl Geophys 116:931-942
Aydin A, Borja RI, Eichhubl P (2006) Geological and mathematical framework for failure modes in granular rock. J Struct Geol 28:83-98. https://doi.org/10.1016/j.jsg.2005.07.008

Aydin A, Johnson AM (1983) Analysis of faulting in porous sandstones. J Struct Geol 5:19-31. https://doi.org/10.1016/01918141(83)90004-4

Ballas G, Fossen H, Soliva R (2015) Factors controlling permeability of cataclastic deformation bands and faults in porous sandstone reservoirs. J Struct Geol 76:1-21. https://doi.org/10.1016/j. jsg.2015.03.01

Ballas G, Soliva R, Sizun J-P, Benedicto A, Cavailhes T, Raynaud S (2012) The importance of the degree of cataclasis in shear bands for fluid flow in porous sandstone, Provence, France. Am Assoc Pet Geol Bull 96:2167-2186. https://doi.org/10.1306/04051 211097

Baud P, Schubnel A, Wong TF (2000) Dilatancy, compaction and failure mode in Solnhofen limestone. J Geophys Res 195:19289-19303

Billi A, Di Toro G (2008) Fault - related carbonate rocks and earthquake indicators: recent advances and future trends. In: Landowe SJ, Hammler GM (eds) Structural geology: new research. Nova Science Publishers, New York, pp 63-86. ISBN 978-1-60456-827-1

Bullock RJ, De Paola N, Holdsworth RE, Trabucho-Alexandre J (2014) Lithological controls on the deformation mechanisms operating within carbonate-hosted faults during the seismic cycle. J Struct Geol 58:22-42. https://doi.org/10.1016/j.jsg.2013.10.00

Cilona A, Baud P, Tondi E, Agosta F, Vinciguerra S, Rustichelli A, Spiers CJ (2012) Deformation bands in porous carbonate grainstones: field and laboratory observations. J Struct Geol 45:137157. https://doi.org/10.1016/j.jsg.2012.04012

Couves C, Roberts S, Racey A, Troth I, Best A (2016) Use of X-ray computed tomography to quantify the petrophysical properties of volcanic rocks: a case study from Tenerife, Canary Islands. J Pet Geol 39:79-94

Doan M-L, d'Hour V (2012) Effect of initial damage on rocks pulverization along faults. J Struct Geol 45:113-124. https://doi. org/10.1016/j.jsg.2012.05.006

Dor O, Ben-Zion Y, Rockwell TK, Brune J (2006) Pulverized rocks in the Mojave section of the San Andreas fault zone. Earth Planet Sci Lett 245:642-654

Dor O, Chester JS, Ben-Zion Y, Brune JN, Rockwell TK (2009) Characterization of damage in sandstones along the Mojave section of the San Andreas Fault: implications for the shallow extent of damage generation. Pure Appl Geophys 166:1747-1773. https:// doi.org/10.1007/s00024-009-0516-Z

Eurocod 7 - PN-EN-1997-2:2009 (2009) Geotechnical design. Design assisted by laboratory testing. European Committee for Standardization

Fisher QJ, Knipe RJ (2001) The permeability of faults within siliciclastic petroleum reservoirs of the North Sea and Norwegian Continental Shelf. Mar Pet Geol 18:1063-1081

Fossen H, Schultz RA, Shipton ZK, Mair K (2007) Deformation bands in sandstone: a review. J Geol Soc London 164:755-769. https:// doi.org/10.1144/0016-76492006-036

Fredrich JT, Evans B, Wong TF (1989) Micromechanics of the brittle to plastic transition in Carrara marble. J Geophys Res 94:4129-4145

Ghaffari HO, Thompson BD, Young RP (2014) Complex networks and waveforms from acoustic emissions in laboratory earthquakes. Nonlinear Process Geophys 21:763-775. https://doi.org/10.5194/ npg-21-763-2014

Griffith WA, Rosakis A, Pollard DD, Ko CW (2009) Dynamic rupture experiments elucidate tensile crack development during propagating earthquake ruptures. Geology 37:795-798. https://doi. org/10.1130/G30064A.1 
Hallbauer DK, Wagner H, Cook NGW (1973) Some observations concerning the microscopic and mechanical behaviour of quarzite specimens in stiff, triaxial compression tests. Int J Rock Mech Min Sci London 10:713-726

Heggheim T, Madland MV, Risnes R, Austad T (2005) A chemical induced enhanced weakening of chalk by seawater. J Pet Sci Eng 46:171-184

Hesthammer J, Fossen H (2000) Uncertainties associated with fault sealing analysis. Pet Geosci 6:37-45

ISRM (2007a) Suggested methods for determining the uniaxial compressive strength and deformability of rock materials. In: Ulusay R, Hudson JA (eds) The complete ISRM suggested methods for rock characterization testing and monitoring: 1974-2006. pp $137-140$

ISRM (2007b) Suggested methods for determining the strength of rock materials in triaxial compression. In: Ulusay R, Hudson JA (eds) The complete ISRM suggested methods for rock characterization testing and monitoring: 1974-2006. pp 159-164

Karnkowski P (1993) Złoża ropy naftowej i gazu ziemnego w Polsce, T. 1 Niż Polski. Tow Geosynoptyków „Geos”, AHG Kraków (in Polish), pp 214

Kemeny JM, Cook NGW (1991) Micromechanics of deformation in rocks. In: Shah SP (ed) Toughening mechanisms in quasi-brittle materials. Kluwer, Klewer Academic, pp 155-188

Ketcham RA, Carlson WD (2001) Acquisition, optimization and interpretation of X-ray computed tomographic imagery: applications to the geosciences. Comp Geosci 27:381-400

Kijewski P (1981) Dolomityzacja skał węglanowych Ca1 w rejonie kopalni rud miedzi. Przegl Geol 10:501-507 (in Polish, with English summary and figure captions)

King GCP, Sammis CG (1992) The mechanisms of finite brittle strain. Pure Appl Geophys 138(4):611-640. https://doi.org/10.1007/ BF00876341

Knipe RJ, Fisher QJ, Jones G, Clennell MR, Farmer AB, Harrison A, Kidd B, Mcallister E, Porter JR, White EA (1997) Fault seal analysis: successful methodologies application and future directions. Npf Sp Publ 7:15-38. https://doi.org/10.1016/S0928 -8937(97)80004-5

Leveille GP, Knipe RJ, More C, Ellis D (1997) Compartmentalization of Rotliegendes gas reservoirs by sealing faults, Jupiter Fields area, southern North Sea. Geolo Soc Lond Spec Publ 123:87-104. https://doi.org/10.1144/GSL.SP.1997.123.01.06

Lucia FJ (2007) Carbonate reservoir characterization. Springer, New York, p 336

Łukaszewski P (2007) Deformation properties of flysch sandstones under conventional triaxial compression conditions. Arch Min Sci 52:371-385

Łukaszewski P (2013) The deformation of flysch sandstones in complex state of stress. Wydawnictwo Uniwersytetu Warszawskiego, Warszawa, p 221 (in Polish)

Moos D, Peska P, Finkbeiner T, Zoback M (2003) Comprehensive wellbore stability analysis using quantitative risk assessment. J Pet Sci Eng Spec Issue Wellbore Stab 38:97-109

Oszczepalski S (1980) Paleogeography, sedimentation and mineralization of the Z1 carbonate series (Zechstein) in the western part of the Fore-Sudetic Monocline (western Poland). Contrib Sedimentol 9:307-323

Ottesen S, Zheng RH, McCann RC (1999) Borehole stability assessment using quantitative risk analysis. Paper presented at the 1999 SPE/IADC drilling conference, Amsterdam, The Netherlands

Patel MB, Shah MV (2015) Strength characteristics for limestone and dolomite rock matrix using tri-axial system. Int J Sci Tech Eng $1: 114-124$

Peryt TM (1978) Sedimentology and paleoecology of the Zechstein Limestone (Upper Permian) in the Fore-Sudetic area (western Poland). Sediment Geol 20:217-243
Peryt TM (1984) Sedimentation and early diagenesis of the Zechstein Limestone in Western Poland. Pr Inst Geol 109:1-70 (in Polish, with English summary and figure captions)

Peryt TM, Oszczepalski S (2007) Facje i paleogeografia wapienia cechsztyńskiego. In: Piestrzyński A (ed) Monografia KGHM Polska Miedź SA, KGHM Cuprum sp. z o.o., Lubin, pp 95-97 (in Polish)

Peryt TM, Ważny H (1980) Microfacies and geochemical development of the basin facies of the Zechstein Limestone (Ca1) in western Poland. Contrib Sedimentol 9:279-306

Peryt TM, Geluk MC, Mathiesen A, Paul J, Smith K (2010) Zechstein. In: Doornenbal JC, Stevenson AG (eds) Petroleum geological atlas of the southern Permian Basin Area. EAGE Publications b.v, Houten, pp 123-147

Piestrzyński S (2007) Geneza złoża. In: Piestrzyński A (ed) Monografia KGHM Polska Miedź SA, Lubin, pp 282-284 (in Polish)

Pinińska J, Domonik A, Dziedzic A, Łukasiak D (2015) The methodology of a complex engineering-geological approach to establish a geopark: case study of the Malopolska Wisla River Gorge. Geol Q 59:408-418

PN-EN 1926:2007 (2007) Natural stone test methods - Determination of compressive strength. Polish Committee for Standardization

PN-G-04302-97 (1997) Compact rocks - Determination of the tensile strength by compression method. Polish Committee for Standardization (in Polish)

Podemski M (1973) Dedolomityzacja utworów cechsztyńskich w rejonie Lubina. Geol Q 17:487-496 (in Polish, with English summary and figure captions)

Poprawa P, Kiersnowski H (2010) Tight gas accumulations in Rotliegend sandstones of Poland (in Polish with English summary). Biul Państwowego Inst Geol 439:173-180

Poszytek A (2014) Reservoir properties of the Upper Rotliegend and the Weissliegend sandstones (Permian) in the Zielona Góra Basin (western Poland). Geol Q. https://doi.org/10.7306/ gq. 1140

Poszytek A, Dudek L, Rożek R (2018) Presence of natural gas in basinal facies of the Zechstein Limestone in a copper mine in SW Poland. J Pet Geol 41:67-83

Poszytek A, Mikołajewski Z, Dohnalik M (2017) X-ray microtomography characterization of porosity in Rotliegendes sandstones on the northern slope of the Wolsztyn Ridge, Western Poland. Geol Q. https://doi.org/10.7306/gq.1314

Poszytek A, Suchan J (2016) A tight gas reservoir in the basinal facies of the Upper Permian Ca1 in the southwestern Zechstein Basin, Poland. Facies. https://doi.org/10.1007/s10347-015-0453-5

Reches Z, Lockner DA (1994) Nucleation and growth of faults in brittle rocks. J Geophys Res 99:18159-18173. https://doi. org/10.1029/94JB00115

Rempe M, Mitchell T, Renner J, Nippress S, Ben-Zion Y, Rockwell T (2013) Damage and seismic velocity structure of pulverized rocks near San Andreas Fault. J Geophys Res Solid Earth 118:28132831. https://doi.org/10.1002/jgbr.50184

Riedel W (1929) Zur Mechanik geologischer Brucherscheinumgen. Zentralblatt für Mineral. Geologie und Paläontologie, Abt B

Risnes R, Flaageng O (1999) Mechanical properties of chalk with emphasis on chalk-fluid interactions and micromechanical aspects. Oil Gas Sci Technol 54:751-758. https://doi.org/10.2516/ ogst: 1999063

Rotevatn A, Tveranger J, Howell JA, Fossen H (2009) Dynamic investigation of the effect of a relay ramp on simulated fluid flow: geocellular modeling of the Delicate Arch Ramp, Utah. Pet Geosci $15: 45-58$

Rybak-Ostrowska B, Konon A, Domonik A, Poszytek A, Uroda J (2017) Shallow generated damage within non-planar strikeslip fault zones - role of the sedimentary rocks in the slip 
accommodation, SW Holy Cross Mountains, Poland. Int J Earth Sci (Geologische Rundschau) 106:1863-1888. https://doi. org/10.1007/s00531-016-1390-4

Sabatakakis N, Koukis G, Tsiambaos G, Papanakli S (2008) Index properties and strength variation controlled by microstructure for sedimentary rocks. Eng Geol 97:80-90. https://doi.org/10.1016/j. enggeo.2007.12.004

Sammis CG, Ashby MF (1986) The failure of brittle porous solids under compressive stress states. Acta Metall 34:511-526

Samudrala O, Huang Y, Rosakis AJ (2002) Subsonic and intersonic shear rupture of weak planes with a velocity weakening cohesive zone. J Geophys Res. https://doi.org/10.1029/2001JB000460

Shipton ZK, Evans JP, Roberson KR, Forster CB, Snelgrove S (2002) Structural heterogeneity and permeability in faulted eolian sandstone: Implications for subsurface modeling of faults. Am Assoc Pet Geol Bull 86:863-883

Sibson RH (1977) Fault rocks and fault mechanisms. J Geol Soc 133:191-213

Soliva R, Schultz RA, Ballas G, Taboada A, Wibberley CAJ, Saillet E, Benedicto A (2013) A model of strain localization in porous sandstone as a function of tectonic setting, burial and material properties; new insight from Provence (SE France). J Struct Geol 49:50-63

Stock SR (2008) Micro computed tomography: methodology and applications. CRC Press, Boca Raton, p 364

Svitelman V, Dinariev O (2013) Geostatistical approach to the anisotropy analysis of $3 \mathrm{D}$ rock microtomographic models. Comp Geosci $57: 116-123$

Tarasov BG, Guzev MA, Sadovskii VM, Cassidy MJ (2017) Modelling the mechanical structure of extreme shear ruptures with friction approaching zero generated in brittle materials. Int J Fract 207:87-97

Tueckmantel C, Fisher QJ, Manzocchi T, Skachkov S, Grattoni CA (2012) Two phase fluid flow properties of cataclastic fault rocks: implication for $\mathrm{CO}_{2}$ storage in saline aquifers. Geology 20:39-42

Vajdova V, Baud P, Tf W (2004) Compaction, dilatancy and failure in porous carbonate rocks. J Geophys Res. https://doi. org/10.1029/2003JB002508
Vajdova V, Baud P, Wu L, Tf W (2012) Micromechanics of inelastic compaction in two allochemical limestones. J Struct Geol 43:100-117

Vajdova V, Zhu W, Chen TMN, Tf W (2010) Micromechanics of brittle faulting and cataclastic flow in Tavel limestone. J Struct Geol 32:1158-1169

Van Geet M, Swennen R, Wevers M (2001) Towards 3-D petrography: application of microfocus computer tomography in geological science. Comp Geosci 27:1091-1099

Wagner R (1994) Stratygrafia osadów i rozwój basenu cechsztyńskiego na Niżu Polskim. Pr Państwowego Inst Geol 146:1-71 (in Polish, with English summary and figure captions)

Wong TF, Baud P (2012) The brittle-ductile transition in porous rock: a review. J Struct Geol 44:25-53. https://doi.org/10.1016/j. jsg.2012.07.010

Woodcock NH, Mort K (2008) Classification of fault breccias and related fault rocks. Geol Mag 145:435-440

Xu S, Ben-Zion Y (2017) Theoretical constraints on dynamic pulverization of fault zone rocks. Geophys J Int 209:282-296

Yuan F, Prakash V, Tullis T (2011) Origin of pulverized rocks during earthquake fault rupture. J Geophys Res 116:B06309. https://doi. org/10.1029/2010JB007721

Zapalski MK, Dohnalik M (2013) Blastogeny in tabulate corals: case studies using X-ray microtomography. Lethaia 46:223-231

Zhu W, Baud P, Vinciguerra S, Tf W (2011) Micromechanics of brittle faulting and cataclastic flow in Alban ssHills tuff. J Geophys Res 116:B06209. https://doi.org/10.1029/2010JB008046

Zoback DM (2007) Reservoir geomechanics. University Press, Cambridge, $\mathrm{p} 449$

Zoback MD, Barton CB, Brudy M, Castillo DA, Finkbeiner T, Grollimund BR, Moos DB, Peska P, Ward CD, Wiprut DJ (2003) Determination of stress orientation and magnitude in deep wells. Int $\mathrm{J}$ Rock Mech Min Sci 40:1049-1076 